\title{
Commonality in Liquidity: A Global Perspective*
}

\author{
Paul BROCKMAN \\ University of Missouri - Columbia \\ Dennis Y. CHUNG \\ Simon Fraser University \\ Christophe PÉRIGNON \\ Simon Fraser University
}

First Draft: March 15, 2006

This Draft: April 18, 2006

\begin{abstract}
:
We conduct the first comprehensive study of commonality in liquidity using intraday spread and depth data from 47 stock exchanges. We show that commonality is a widespread, global phenomenon. Firm-level changes in spreads and depths are significantly influenced by exchange-wide changes in liquidity on the majority of the world's stock exchanges. Emerging Asian exchanges have exceptionally strong commonality, while those of Latin America exhibit little if any commonality. In contrast to previous NYSE-based results, we find that commonality in bid-ask spreads is most prevalent among small firms while commonality in depths increases monotonically with firm size. After documenting the pervasive role of commonality within individual exchanges, we examine commonality across exchanges. We extend the empirical model of Chordia, Roll, and Subrahmanyam (2000) and find the first empirical evidence of a distinct, global component in bid-ask spreads and depths. Changes in global spreads and depths have a significant effect on changes in liquidity at the exchange level. We show that while exchange size (total market capitalization) plays an influential role in the liquidity transmission process, global commonality is not driven by a subset of large exchanges.
\end{abstract}

\section{JEL Classification: G10, G15}

Keywords: Liquidity, Commonality, Bid-Ask Spreads, Depths

* Contact author: Paul Brockman, Department of Finance, College of Business, University of Missouri-Columbia, Columbia, MO 65211; phone: 573-884-1562, fax: 573884-6296, email: brockmanp@missouri.edu. 


\section{Commonality in Liquidity: A Global Perspective}

\section{Introduction}

Commonality in liquidity refers to the impact of a common or market-wide liquidity factor on an individual firm, both in terms of bid-ask spreads and depths. Previous empirical research has shown that there exists a significant common component that influences firm-level liquidity. Simply stated, liquidity is subject to a spillover effect that influences other firms trading in the same market. Although there is some evidence of commonality on non-US exchanges (Fabre and Frino (2004) and Brockman and Chung (2002)), most previous studies investigate firms trading in the US (Chordia, Roll, and Subrahmanyam (2000), Hasbrouck and Seppi (2001), and Huberman and Halka (2001)). But regardless of the particular market investigated, all previous studies using intraday bid-ask spreads and depths are single-exchange studies. The purpose of our paper is twofold. First, we conduct a comprehensive investigation of commonality in liquidity for 47 stock exchanges using intraday spread and depth data. Second, we examine the impact of a global liquidity factor on spread and depth commonality at the level of the exchange. The size, scope, and cross-sectional variation of our database allow us to analyze several aspects of commonality that previous, single-exchange studies could not address.

It is important to understand secondary-market liquidity because of the various roles it plays in the capital markets. Liquidity encourages trading by reducing transaction costs. A market participant's ability to capture potential gains of trade depends directly on liquidity levels. There is an economic welfare benefit from liquid markets because trading is the mechanism through which information is impounded into prices. More 
informative prices lead to more efficient allocations of capital across competing investments (Wurgler (2000)). Liquidity also plays a significant role in determining the firm's cost of capital. The more liquid the firm's stock, the lower the cost of capital (Amihud and Mendelson (1986), Brennan and Subrahmanyam (1996), Datar, Naik, and Radcliffe (1998), and Easley, Hvidkjaer, and O'Hara (2002)); and the lower the firm's cost of capital, the higher the market capitalization. For all of these reasons, there is considerable interest among managers, investors, exchange members, and regulators in understanding the determinants of secondary-market liquidity.

Most of the early liquidity studies analyze firm-specific determinants of liquidity. This line of research has shown that variations in price, volume, and volatility explain much of the cross-sectional variation in bid-ask spreads (Benston and Hagerman (1974), Stoll (1978), Barclay and Smith (1988), Franz, Rao, and Tripathy (1995), and Noronha, Sarin, and Saudagaran (1996)) and depths (Brockman and Chung (1999)). More recent research focuses on the common components of firm liquidity (i.e., changes in firm-level bid-ask spreads and depths caused by changes in market-level spreads and depths). This line of research has shown that individual firm liquidity is sensitive to changes in aggregate liquidity movements (Chordia, Roll, and Subrahmanyam (2000), Coughenour and Saad (2004), and Chordia, Sarkar, and Subrahmanyam (2005)). One implication of these findings is that sensitivity to aggregate liquidity movements might represent a systematic risk factor (Pastor and Stambaugh (2003), Acharya and Pedersen (2005), and Stahel (2003)).

Over the past three decades, capital markets have become increasingly globalized because of lower information technology costs and a movement toward deregulation and 
free trade on the part of national governments. Concomitant with globalized capital movements are globalized liquidity movements. Commenting on these global movements, Peter Weinberg, former chief executive officer of Goldman Sachs International (2006), states that "liquidity and the movement of capital around the world have become so ubiquitous and pervasive that it is hard to know where London or New York begins and where Tokyo, Shanghai or Hong Kong leaves off.” A primary objective of our study is to examine the relation between liquidity changes in London or New York, for instance, and liquidity movements in Tokyo, Shanghai, Hong Kong, and the rest of the world.

To date, our knowledge of spread and depth co-movements is limited to empirical evidence from only a handful of individual stock exchanges (US, Hong Kong, and Australia). ${ }^{1}$ This limitation means that many important questions remain unanswered. Is commonality in spreads and depths widespread across the world's stock exchanges? Is commonality a more serious problem for emerging or developed markets? Does firm size or industry play a significant role in transmitting liquidity shocks across firms? Is there a global component to commonality in liquidity? We address these and related questions by accessing a global Bloomberg database that encompasses 1.47 billion transactions across 47 stock exchanges, 38 countries, and the six major regions as defined by Morgan Stanley Capital International (MSCI).

We divide our empirical investigation into two main sections. In the first section, we use the methodology of Chordia, Roll, and Subrahmanyam (2000) to measure

\footnotetext{
${ }^{1}$ Stahel (2003) uses monthly returns and turnover to investigate co-movement among the US, Japanese, and the UK stock markets. Stahel (2005) uses a weekly illiquidity measure to examine liquidity across 18 developed and emerging markets. No previous study, however, analyzes global commonality in bid-ask spreads or depths.
} 
commonality in spreads and depths for each of our 47 stock exchanges. Our results verify that exchange-level commonality is a pervasive phenomenon across the globe. On most, but not all, exchanges individual firms' spreads and depths are significantly influenced by changes in the aggregate market's spreads and depths. Although most exchanges have a significant commonality component, there are also large cross-sectional variations among exchanges and geographic regions. The stock exchanges of Emerging Asia, for example, exhibit the strongest commonality in spreads, while the exchanges of North America have the strongest commonality in depths. Latin American stock exchanges exhibit very little commonality at the exchange level.

We also investigate the roles of firm size and industry within each of our exchanges. In contrast to Chordia, Roll, and Subrahmanyam's (2000) NYSE-based results, we find that commonality in bid-ask spreads is most prevalent among smaller firms. Depth commonality, on the other hand, exhibits a positive relation with firm size. Our industry results show that while commonality is significant in each of our ten global industries, there is considerable variation across industries. The Utilities industry, for example, is much less susceptible to commonality in spreads than the Consumer Cyclical industry. Comparing our global results to Chordia, Roll, and Subrahmanyam's (2000) NYSE findings, we find that the industry effect is much more prominent for NYSE firms than for the typical global firm.

Our global evidence shows definitively that commonality in liquidity is widespread within individual stock exchanges. In our second section, we examine the possible existence of commonality in liquidity across stock exchanges. Is exchange-level liquidity influenced by regional or global liquidity movements? Does the sensitivity of 
exchange-level liquidity to global commonality depend on the size of the exchange? Are emerging markets more or less susceptible to global commonality than developed markets? To answer these and related questions, we extend the empirical model of Chordia, Roll, and Subrahmanyam (2000) in order to measure the impact of changes in global liquidity on changes in aggregate exchange-level liquidity. To the best of our knowledge, no previous study has examined global commonality in spreads and depths.

Our empirical tests generate several new findings. We find unambiguous support for the hypothesis that commonality in liquidity spills across national borders. Movements in aggregate bid-ask spreads and depths on an individual exchange are significantly influenced by movements in spreads and depths at the global scale. We show that both developed and emerging markets are susceptible to global commonality, although developed markets are more sensitive to liquidity spillover effects than emerging markets. We also show that global commonality is not driven solely by regional co-movements. For developed markets, a larger portion of spread and depth commonality is attributable to regional as opposed to global (i.e., non-regional) sources. For emerging markets, the global source dominates the regional source. Finally, we show that the total market capitalization of the exchange plays a significant role in the liquidity transmission process.

In summary, our results verify that neither firm- nor exchange-level liquidity can be understood in isolation. Individual firm liquidity is significantly influenced by comovements in the liquidity of all other firms traded on the same exchange. This result is widespread across most exchanges in the world. In a parallel manner, exchange-level liquidity is significantly influenced by co-movements in the global liquidity of all other 
exchanges. This global commonality result holds even in the absence of the large, influential exchanges located in New York, London, and Tokyo.

In the next section, we discuss our database and method of analysis. In section three, we present and interpret our empirical findings. In section four, we summarize and conclude our study.

\section{Data and Method of Analysis}

We obtain trade and quote data from the Bloomberg financial information network. Bloomberg receives real-time bid and ask quotes and transaction data for stocks traded on global markets through a live feed directly from the exchanges. Intra-day data on the US exchanges, not available from Bloomberg due to data licensing restrictions, are obtained from the NYSE's Trade and Quote (TAQ) database. We compile intra-day bidask spread and depth measures over a 21-month period from October 1, 2002 to June 30, 2004 (i.e., 455 trading days). We require a minimum of 200 days with at least one trade during the sample period in order to eliminate inactively traded firms. Firms with market capitalization less than $\$ 100$ million and exchanges with less than ten sample firms are also excluded from our analysis. Our final sample contains 1.47 billion transactions across 47 stock exchanges, 38 countries, and the six major regions as defined by MSCI. ${ }^{2}$ After calculating daily averages, we have 3,838,241 daily observations representing the number of firm-days with trades for all of our 9,427 firms.

\footnotetext{
${ }^{2}$ These 1.47 billion transactions are extracted from roughly 15 billion quote and trade observations over our 21-month sample period.
} 


\subsection{Descriptive Statistics}

We present descriptive statistics for our global database in Table 1. We report the exchange, country, MSCI region, number of firms, total market capitalization, average dollar trading volume, average number of trades, percentage of days with trades, average relative effective spreads, and average dollar value depths. ${ }^{3}$ All averages are calculated on a per firm, per day basis. The developed-market group includes 16 European exchanges, four North American exchanges, and seven Pacific exchanges; the emergingmarket group includes 11 Asian exchanges, four European, Middle Eastern, and African exchanges, and five Latin American exchanges.

Our descriptive statistics reveal considerable cross-sectional variation both within the six regions and (especially) across these regions. The number of actively traded firms varies from a low of 13 for the Budapest and Lima Stock Exchanges to a high of 1,515 for Nasdaq; total market capitalization ranges from $\$ 6.8$ billion for Korea’s KOSDAQ to $\$ 9,092.1$ billion for the NYSE; average trading volume ranges from $\$ 5.6$ thousand on the Istanbul Stock Exchange to $\$ 50,596.3$ thousand on Switzerland's Virt-X; and the average number of daily trades varies from four on the Johannesburg Stock Exchange to 1,697 on KOSDAQ. Most exchanges have a large percent of days with active trades.

In the last two columns of Table 1, we report average relative effective spreads and average dollar depths. We define relative effective spreads as twice the absolute value of the transaction price deviation from the bid-ask midpoint, divided by the bid-ask midpoint. We define dollar depths (or depth in value) as the number of shares at the bid

\footnotetext{
${ }^{3}$ We convert local currency amounts into US dollars using the daily historical spot exchange rates obtained from Bloomberg.
} 
and ask prices multiplied by their corresponding prices (in US dollar terms). ${ }^{4}$ Over half of the exchanges in our sample have relative spreads that are less than one percent of the bid-ask midpoint. Only three stock exchanges (Jakarta, Sao Paulo, and Lima) have relative spreads that exceed two percent. Of the nine exchanges with relative spreads less than 0.5 percent, seven are located in Asia (Shanghai, Shenzhen, Bombay, National Stock Exchange of India, Tokyo, KOSDAQ, and the Korea Exchange), one in Europe (Virt-X), and one in North America (NYSE). Our dollar depth figures vary from a low of $\$ 523$ for the Istanbul Stock Exchange to $\$ 827,649$ for the electronic Virt-X. ${ }^{5}$

\subsection{Method of Analysis}

In the first section of our analysis, we apply the methodology of Chordia, Roll, and Subrahmanyam (2000) to our 47 stock exchanges. For each exchange, we test for commonality in liquidity using the following firm-by-firm time series regression:

$$
\begin{gathered}
\Delta \text { Liquidity }_{F, t}=\alpha+\beta_{1} \Delta \text { Liquidity }_{E, t}+\beta_{2} \Delta \text { Liquidity }_{E, t+1}+\beta_{3} \Delta \text { Liquidity }_{E, t-1}+ \\
\delta_{1} \text { Return }_{E, t}+\delta_{2} \text { Return }_{E, t+1}+\delta_{3} \text { Return }_{E, t-1}+\delta_{4} \Delta \text { Volatility }_{F, t}+\varepsilon_{F, t}
\end{gathered}
$$

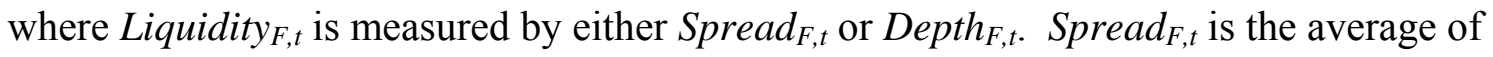
intra-day relative effective bid-ask spreads for firm $F$ on day $t$. Similarly, $\operatorname{Depth}_{F, t}$ is the average of intra-day dollar depths for firm $F$ on day $t$. Volatility V $_{t, t}$ is the return volatility for firm $F$ on trading day $t$ and is measured as the average squared return. Liquidity $_{E, t}$ is an equal-weighted average of each corresponding liquidity measure for all firms trading

\footnotetext{
${ }^{4}$ In addition to relative effective bid-ask spreads, we also test for commonality in liquidity using (1) effective spreads, (2) quoted spreads, and (3) relative quoted spreads. In addition to dollar depths, we also test for commonality using share depths. Our conclusions are unchanged by these alternative definitions of liquidity.

${ }^{5}$ Our Bloomberg database does not include depth figures for two exchanges: the New Zealand Exchange and the London Stock Exchange.
} 
on the same stock market. ${ }^{6}$ Return $_{E, t}$ is the equal-weighted average of the daily return for all firms trading on the same stock market. All dependent and independent variables are expressed in terms of proportional changes (denoted as $\Delta$ ) in the variable across successive trading days. All exchange averages exclude the dependent-variable firm; that is, Liquidity $_{E, t}$ and Return $_{E, t}$ are calculated using all firms on the exchange except firm $F$. Our primary variable of interest is the contemporaneous coefficient on $\Delta$ Liquidity $_{E, t}$ (i.e., $\beta_{1}$ ). A positive and significant $\beta_{1}$ would mean that exchange-level liquidity changes exert a substantial influence on firm F's liquidity.

We also test for industry-wide commonality at the exchange level by using the following regression model:

$$
\begin{array}{r}
\Delta \text { Liquidity }_{F, t}= \\
\quad \alpha+\beta_{1} \Delta \text { Liquidity }_{E, t}+\beta_{2} \Delta \text { Liquidity }_{E, t+1}+\beta_{3} \Delta \text { Liquidity }_{E, t-1}+ \\
\gamma_{1} \Delta \text { Liquidity }_{E I, t}+\gamma_{2} \Delta \text { Liquidity }_{E I, t+1}+\gamma_{3} \Delta \text { Liquidity }_{E I, t-1}+ \\
\delta_{1} \text { Return }_{E, t}+\delta_{2} \text { Return }_{E, t+1}+\delta_{3} \text { Return }_{E, t-1}+\delta_{4} \Delta \text { Volatility }_{F, t}+\varepsilon_{F, t}
\end{array}
$$

where Liquidity $E_{E I, t}$ (i.e., exchange-level industry liquidity) is the equally-weighted average of the respective liquidity measure for all firms in the industry. All other variables are the same as defined above in model (1). Our primary variable of interest in regression model (2) is the contemporaneous coefficient on $\Delta$ Liquidity $_{E I, t}$.

In the second section of our analysis, we extend the methodology of Chordia, Roll, and Subrahmanyam (2000) to capture the influence of global commonality on exchange-level liquidity. We test for a global commonality influence on exchange-level liquidity by estimating the following time series regression:

\footnotetext{
${ }^{6}$ It is possible to use an equally-weighted average or a value-weighted average in constructing the market average. Although we report the equally-weighted results in subsequent sections, re-running our analysis using value-weighted averages does not alter our conclusions.
} 


$$
\begin{gathered}
\Delta \text { Liquidity }_{E, t}=\alpha+\beta_{1} \Delta \text { Liquidity }_{G, t}+\beta_{2} \Delta \text { Liquidity }_{G, t+1}+\beta_{3} \Delta \text { Liquidity }_{G, t-1}+ \\
\delta_{1} \text { Return }_{G, t}+\delta_{2} \text { Return }_{G, t+1}+\delta_{3} \text { Return }_{G, t-1}+\delta_{4} \Delta \text { Volatility }_{E, t}+\varepsilon_{E, t}
\end{gathered}
$$

${\text { where } \text { Liquidity }_{G, t} \text { and Return }}_{G, t}$ are equal-weighted averages across all firms in our global database, except those firms trading on exchange $E$. The primary variable of interest in regression model (3) is the contemporaneous coefficient on $\Delta$ Liquidity $_{G, t}$. A positive and significant $\beta_{1}$ would mean that global liquidity changes (excluding exchange $E$ ) exert a substantial influence on exchange E's liquidity.

And finally, we test for regional effects in liquidity using the following regression model:

$$
\begin{array}{r}
\Delta \text { Liquidity }_{E, t}=\begin{array}{c}
\alpha+\beta_{1} \Delta \text { Liquidity }_{G, t}+\beta_{2} \text { L }_{\text {Liquidity }}^{G, t+1}+\beta_{3} \Delta \text { Liquidity }_{G, t-1}+ \\
\gamma_{1} \Delta \text { Liquidity }_{R, t}+\gamma_{2} \Delta \text { Liquidity }_{R, t+1}+\gamma_{3} \Delta \text { Liquidity }_{R, t-1}+ \\
\delta_{1} \text { Return }_{G, t}+\delta_{2} \text { Return }_{G, t+1}+\delta_{3} \text { Return }_{G, t-1}+\delta_{4} \Delta \text { Volatility }_{E, t}+\varepsilon_{E, t}
\end{array}
\end{array}
$$

where Liquidity ${ }_{R, t}$ (i.e., regional liquidity) is the regional liquidity index computed on day $t$ using an equal-weighted average of each corresponding liquidity measure for all firms trading on an exchange located in the same MSCI region as exchange E. All other variables are the same as defined above. Similar to regression (2) where we distinguish industry from exchange effects, regression (4) allows us to differentiate regional from global commonality influences.

In summary, our research method is designed to capture not only the existence of commonality in liquidity at various levels but also to identify the source of that commonality. We test for global commonality in exchange-level liquidity after eliminating all exchange-related commonality. The results of this analysis will provide answers to the unresolved issues discussed above. We turn next to these empirical results. 


\section{Empirical Results}

We divide our empirical findings into two main sections. The first section investigates the pervasiveness of co-movements in liquidity by estimating Chordia, Roll, and Subrahmanyam's (2000) commonality measures for each of our 47 exchanges (regression models (1) and (2)). The second section examines commonality in liquidity at the global scale. We estimate global and regional commonality measures for aggregate exchange-level liquidity (regression models (3) and (4)). In both sections, we investigate the influence of size and industry on commonality.

\subsection{Exchange-Level Commonality}

In Table 2, we report the following relative effective bid-ask spread results for each of our 47 stock exchanges: average and median contemporaneous liquidity coefficients from regression model (1); the percent of firms with positive and significant coefficients, positive and insignificant coefficients, negative and insignificant coefficients, negative and significant coefficients; median sum of lead, lag, and contemporaneous coefficients; and the $p$-value of this sum. Unless otherwise stated, we use a significance level of five percent to differentiate significant from insignificant results.

Our findings in Table 2 provide strong support for the postulation that changes in the individual firm's bid-ask spreads are significantly influenced by a common (exchange-wide) liquidity factor. These results confirm that commonality in liquidity is ubiquitous across the world's stock exchanges. Forty-three of the 47 exchanges have a positive average contemporaneous coefficient, and 46 of the 47 exchanges have a 
positive median coefficient. ${ }^{7}$ Forty-four exchanges have positive and significant coefficients that exceed the null hypothesis of five percent, 33 exchanges have ten percent or more of their firms with positive and significant coefficients, and 23 exchanges have 20 percent or more of their firms with positive and significant coefficients. ${ }^{8}$

Turning to the percent of firms with negative and significant contemporaneous coefficients, we find that only four exchanges (Vienna, Jakarta, Budapest, and Buenos Aires) exceed the null hypothesis of five percent. The Buenos Aires Stock Exchange is the only exchange with 10 percent or more of its firms (10.53\%) exhibiting negative and significant coefficients. In addition to the asymmetry in significant coefficients, there is also a strong positive skewness in the percent of firms with insignificant coefficients. All exchanges but one (Santiago) have a higher proportion of firms with positive and insignificant coefficients relative to negative and significant coefficients. For well over half of the exchanges, the percent of firms with positive and insignificant coefficients is more than double the percent of firms with negative and insignificant coefficients.

The median values for the sum of lead, lag, and contemporaneous coefficients are overwhelmingly positive. The Santiago Stock Exchange is the only exchange with a negative median value $(-0.1415)$, and it is insignificant at the five percent level $(p$-value $=$ 0.222). Twenty-nine of the 46 exchanges with positive combined (SUM) coefficients are statistically significant at the five percent level, with 26 exchanges significant at the one percent level.

\footnotetext{
${ }^{7}$ The four exchanges with negative average coefficients include the Stock Exchange of Thailand, Buenos Aires Stock Exchange, Sao Paulo Stock Exchange, and Santiago Stock Exchange. The only exchange with a negative median coefficient is the Santiago Stock Exchange.

${ }^{8}$ The Budapest Stock Exchange, Santiago Stock Exchange, and JASDAQ are the only three exchanges on which less than five percent of firms have positive and significant contemporaneous coefficients.
} 
Our global data and research design also enable us to identify cross-sectional differences in spread commonality across stock exchanges. Median contemporaneous coefficients range from a low of -0.1123 for the Santiago Stock Exchange to a high of 1.1251 for the London Stock Exchange. Besides London, there are eight other exchanges with contemporaneous coefficients greater than 0.50 ; these include the stock exchanges of Toronto, Nasdaq, Tokyo, Shanghai, Shenzhen, Bombay, Taiwan, and the National Stock Exchange of India. Several of these same exchanges also have a high percent of firms with significant coefficients. The stock exchanges of Shanghai, Shenzhen, Bombay, Taiwan, Virt-X, Istanbul, and the National Stock Exchange of India all have 80 percent or more of their firms with positive and significant coefficients. It is interesting to note that some of the strongest commonality-in-liquidity patterns appear in the emerging Asian markets.

In Table 3, we examine commonality in depth across 45 stock exchanges. These empirical results also provide strong support for the claim that changes in the individual firm's depths are significantly influenced by a common liquidity factor. Thirty-eight of the 45 exchanges have a positive average contemporaneous coefficient; 40 exchanges have a positive median coefficient. Forty-two exchanges have positive and significant coefficients that exceed the null hypothesis of five percent, while 36 exchanges have ten percent or more of their firms with positive and significant coefficients. Unlike our commonality-in-spreads findings, no stock exchange has negative and significant commonality coefficients exceeding five percent. The highest percent of negative and significant coefficients is only 3.85 percent from the Warsaw Stock Exchange. Similar to 
our commonality-in-spreads findings, the weakest evidence for commonality is concentrated on the Emerging Latin American exchanges.

The median values for the sum of lead, lag, and contemporaneous depth coefficients are mostly positive and significant. Twenty-eight of the 39 exchanges with positive combined (SUM) coefficients are statistically significant at the five percent level, with 24 exchanges significant at the one percent level. Only two exchanges, Euronext Paris and the Athens Stock Exchange, have median SUM values (-0.0156, and -0.0074, respectively) that are significant at the five percent level.

Similar to the cross-sectional differences in spread commonality, we find considerable variation in depth commonality across stock exchanges. Median contemporaneous coefficients vary from a low of -0.0212 for the Sao Paulo Stock Exchange to a high of 1.3870 for the Spanish Continuous Market. In addition to the Spanish exchange, there are 11 other exchanges with contemporaneous median coefficients greater than 0.50; six of these 11 exchanges are located in Emerging Asia. ${ }^{9}$

In Table 4, we aggregate our spread and depth findings by geographic region and by emerging versus developed markets. Panel A reports the bid-ask spread results at the global, developed, and emerging market levels. We use the MSCI categories to further divide our developed markets into European, North American, and Pacific regions; and our emerging markets into Asian, Latin American, and Europe, Middle East, and Africa regions. Panel B follows the same format for depths.

\footnotetext{
${ }^{9}$ As a robustness check, Chordia, Roll, and Subrahmanyam (2000) test for cross-equation dependencies by running time series regressions on the residuals of paired companies. They report that the mean level of dependency is insufficient to significantly affect their overall results. We apply the same method and run time series regressions on the residuals of randomly arranged adjacent companies. At the $5 \%$ level, the proportion of significant $t$-values are 4.32 and 4.27 percent for our spread and depth residual regressions, respectively. These figures are lower than the comparable numbers, 12.33 and 11.73 percent, reported by Chordia, Roll, and Subrahmanyam (2000).
} 
Turning to the results in Panel A, we find that the average (median)

contemporaneous spread coefficient is $0.5986(0.4271)$. These positive coefficients are significant at the five percent level for 48.78 percent of the firms in our global database. The median of the combined lead, lag, and contemporaneous coefficient is 0.4327 and highly significant. We find this same general pattern in the developed markets, where the average (median) contemporaneous spread coefficient is $0.6036(0.3733)$. Almost 43 percent of the developed market firms have positive and significant coefficients. Among the three regions, North American firms are more susceptible to commonality in liquidity than their European counterparts.

For the emerging markets, the average (median) contemporaneous spread coefficient is $0.5845(0.5677)$. Over 66 percent of the emerging market firms have positive and significant coefficients. In sharp contrast to the developed markets, emerging markets exhibit large variations in spread commonality. There is no evidence of spread commonality in the Latin American region, whether one looks at the average or median contemporaneous coefficients, percent of firms with significant coefficients, or the combined lead, lag, and contemporaneous coefficient. The Asian emerging market, on the other hand, has the largest commonality coefficients (average, median, and combined) and the highest percent of significant coefficients across all regions including the developed markets.

In Panel B, we report parallel results for our depth measures. The average (median) contemporaneous depth coefficient is 0.6205 (0.5204), and these coefficients are significant for 41.54 percent of global firms. The median of the combined lead, lag, and contemporaneous coefficient is 0.5343 and highly significant. Similar to the spread 
results in Panel A, the developed market's contemporaneous and combined coefficients are positive and highly significant. Again, the North American firms appear to be more susceptible to commonality in liquidity than their European counterparts. Unlike the spread results in Panel A, all emerging markets display significant commonality in depth liquidity, with the exception of Latin America's combined coefficient. The emerging areas of Europe, Middle East, and Africa, in particular, have large and highly significant contemporaneous depth coefficients.

\subsubsection{Exchange-Level Commonality: Size Effects}

In Table 5, we examine the relation between firm size (i.e., market capitalization) and commonality. Our spread results in Panel A show that average, median, and combined (SUM) coefficients are overwhelmingly positive and significant across all size quintiles. Firms in second-smallest size quintile (Quintile 2) have the highest mean and median coefficients ( 0.7231 and 0.6164 , respectively), while firms in the largest size quintile (Quintile 5) have the smallest mean and median coefficients (0.3986 and 0.2142, respectively). These global findings are in stark contrast to previous size-based results looking at NYSE firms. Chordia, Roll, and Subrahmanyam's (2000) find that large NYSE firms have the highest commonality-in-spread coefficients. On the other hand, these global commonality-in-spread coefficients are consistent with the size-based findings for an order-driven, non-US stock exchange (e.g., the Stock Exchange of Hong Kong) in Brockman and Chung (2002).

Our Panel B depth results show that average, median, and combined (SUM) coefficients are positive and significant across all size quintiles. Firms in the largest size quintile have the highest mean and median coefficients ( 0.7416 and 0.6876 , respectively), 
while firms in the smallest size quintile have the smallest mean and median coefficients (0.5016 and 0.3339, respectively). Unlike the spreads results in Panel A, our depth results show a clear, monotonically-increasing relation between firm size and commonality in depths.

Overall, these findings show that commonality is prevalent across all firm sizes; small firms are more susceptible to commonality in spreads than large firms, but large firms experience more commonality in depths than small firms.

\subsubsection{Exchange-Level Commonality: Industry Effects}

We report exchange-level commonality by industry (regression model (2)) in Table 6. The spread results in Panel A reveal positive and highly significant mean, median, and SUM coefficients. The percent of firms with positive and significant contemporaneous spread coefficients (at the five percent level) varies from a low of 32.51 percent for Utilities to a high of 58.65 percent for Consumer Non-Cyclicals. Every industry has a highly significant and positive median sum of lead, lag, and contemporaneous coefficients (all $p$-values less than 0.001). The Consumer Cyclical industry has the highest mean, median, and SUM coefficients $(0.7532,0.6164$, and 0.6103, respectively), while the Utilities industry has the lowest mean, median, and SUM coefficients $(0.2932,0.1216$, and 0.1345 , respectively).

In Panel B, we report commonality in depth by industry. Similar to the Panel A results, the mean and median contemporaneous depth coefficients are all positive and highly significant. The percent of firms with positive and significant contemporaneous depth coefficients varies from a low of 23.44 percent for the Basic Material industry to a 
high of 74.23 percent for Utilities. All of the combined SUM coefficients are positive and significant at the five percent level.

Looking across the results in Panels A and B, we find some evidence of substitution between spread and depth commonalities. That is, the Utilities industry exhibits the weakest commonality in spreads, but also shows the strongest commonality in depths. The Consumer-related industries (both Cyclical and Non-Cyclical) have the strongest commonality in spreads, and relatively weak commonality in depths. This same pattern is also apparent in our Table 5 size-based results. The smallest (largest) firms are subject to the strongest (weakest) commonality-in-spread liquidity, while the largest (smallest) firms are susceptible to the strongest (weakest) commonality-in-depth liquidity. We are not aware of any market microstructure theory that would predict this empirical pattern.

In addition to categorizing our commonality results by industry, we also estimate commonality in liquidity at the industry level while controlling for commonality in liquidity at the exchange level (i.e., regression model (2)). We report the spread coefficients in Panel A of Table 7, and the depth coefficients in Panel B. For the global spreads results in Panel A, our average (median) contemporaneous coefficient related to industry commonality is $0.1064(0.0334)$. Over ten percent of all firms have positive and significant contemporaneous coefficients, and the SUM coefficient of 0.0344 is highly significant. We find similar results for both the 27 developed and 20 emerging markets. The median coefficients are 0.0340 and 0.0304 , respectively, and they are significant for 10.07 and 11.73 percent of all in-sample firms. 
For the global depth results in Panel B, our average (median) contemporaneous coefficient related to industry commonality is $0.1315(0.0749)$. Over 13 percent of all firms have positive and significant contemporaneous coefficients, and the SUM coefficient of 0.0799 is highly significant. Again, we find similar results for both the developed and emerging markets. The median coefficients are 0.0787 and 0.0662 , respectively, and they are significant for 12.80 and 14.42 percent of in-sample firms.

Overall, the results in Table 7 demonstrate that there is a significant industry component in firm-level liquidity. The industry component is present in spreads and depths, as well as in developed and emerging markets. However, industry-level commonality is not as influential as the exchange-level component in terms of average, median, or SUM coefficient magnitudes or significance levels. Comparing our global findings to Chordia, Roll, and Subrahmanyam's (2000) NYSE findings, we note that the industry effect is much more prominent for NYSE firms than for the typical global firm. For three of their five liquidity measures, Chordia, Roll, and Subrahmanyam (2000) find that contemporaneous and SUM industry coefficients are larger than the respective exchange-level (i.e., NYSE) coefficients. The industry coefficients for NYSE firms are also much larger than for our global firms. ${ }^{10}$ Although these differences could be related to the specialist market structure (Coughenour and Saad (2004)), further research is certainly warranted.

\footnotetext{
${ }^{10}$ Their industry-related spread (SUM) coefficients for NYSE firms range from a low of 0.259 for relative effective spreads to a high of 0.527 for quoted spreads. Their industry-related depth (SUM) coefficient for NYSE firms is 0.480 . In contrast, none of our comparable spread coefficients is larger than 0.0375 , and none of our depth (SUM) coefficients is larger than 0.0854 .
} 


\subsection{Global Commonality}

Our exchange-level results provide direct evidence that the commonality in liquidity found in previous studies for the NYSE is in fact a pervasive phenomenon across most of the world's stock exchanges. We also document cross-sectional variations in commonality at the level of the individual exchange, geographic region (e.g., Pacific, Latin America), developed versus emerging market, size-based quintiles, and industry. We turn now to examining commonality at the global scale. Our primary objective in this section is to determine whether commonality in liquidity has a natural boundary at the exchange's frontier, or whether it spills over onto other exchanges.

\subsubsection{Global Commonality: Comovement across Exchanges}

In Table 8, we investigate the global scope of commonality in liquidity. We use regression model (3) to estimate changes in aggregate exchange liquidity attributable to changes in global liquidity (i.e., excluding the exchange of interest). Panel A reports our spread results and Panel B provides our depth results. The average (median) contemporaneous spread coefficient is $0.1753(0.1764)$ across all stock exchanges. This coefficient is positive and significant at the five percent level for 44.68 percent of our exchanges. It is negative and significant for 2.13 percent of exchanges. The median sum of lead, lagged, and contemporaneous coefficients is 0.2275 , and it is highly significant. These findings represent unambiguous evidence of global commonality in bid-ask spreads.

We investigate global commonality in more detail by dividing our 47 exchanges into 27 developed markets and 20 emerging markets. This partition allows us to analyze separately the global components in developed versus emerging markets, although it also 
reduces the power of our tests by creating two small samples. The developed markets average (median) contemporaneous spread coefficient is 0.2494 (0.2440). Almost 60 percent of these coefficients are positive and significant, and none is negative and significant. The SUM coefficient (0.2546) is significant at the one percent level. Our emerging markets results are similar in significance, if smaller in magnitude. The emerging markets average (median) contemporaneous spread coefficient is 0.0752 (0.1296). Twenty-five percent of these coefficients are positive and significant, and five percent are negative and significant. The median SUM coefficient (0.1234) is significant at the five percent level. Overall, we find that changes in bid-ask spreads strongly covary across both developed and emerging markets.

Turning to the depth results in Panel B, we see that the average (median) contemporaneous depth coefficient is $0.0674(0.0352)$ across all stock exchanges. This coefficient is positive and significant for 26.67 percent of our exchanges, and negative and significant for 4.44 percent of our exchanges. The median SUM coefficient is 0.0750 , and it is significant at the one percent level.

The developed markets average (median) contemporaneous depth coefficient is $0.0711(0.0404)$. Thirty-two percent of these coefficients are positive and significant, while only four percent are negative and significant. The SUM coefficient $(0.1055)$ is positive and significant at the 5.2 percent level. The emerging-markets average (median) contemporaneous depth coefficient is $0.0628(0.0325)$. Twenty percent of these coefficients are positive and significant, and five percent are negative and significant. The median SUM coefficient (0.0614) is positive but insignificant at conventional levels $(p$-value $=0.115)$ 
Overall, our Table 8 findings represent the first empirical evidence of global commonality in spreads and depths. Global commonality in spreads and depths significantly affects both developed and emerging markets, with some evidence that its impact is strongest on the developed market exchanges. ${ }^{11}$

\subsubsection{Global Commonality: Size Effects}

In Table 9, we report global commonality coefficients by exchange size in order to test whether commonality is restricted to exchanges of a given size. We divide all 47 exchanges into small, medium, and large categories based on their total market capitalizations. The spread results in Panel A demonstrate that while spread commonality is significant across all exchange sizes, larger exchanges are more sensitive to liquidity spillover than small exchanges. The average (median) contemporaneous coefficient increases from $0.1664(0.1296)$ for small exchanges to $0.2011(0.2075)$ for large exchanges. Similarly, the percent of exchanges with positive and significant coefficients is 31.25 percent for small exchanges and 68.7 percent for large exchanges, with medium size exchanges somewhere in between. In contrast to Table 5's firm-size results where spread commonality decreases with size, our exchange-based results show that spread commonality increases with size.

The depth results in Panel B reveal that depth commonality is significant across all exchange sizes. Small exchanges are relatively more sensitive to depth-related liquidity spillover than large exchanges. The average (median) contemporaneous coefficient decreases from $0.0926(0.0812)$ for small exchanges to $0.0329(0.0348)$ for

\footnotetext{
${ }^{11}$ Following Chordia, Roll, and Subrahmanyam (2000), we test for cross-equation dependencies by running time series regressions on the residuals of paired exchanges. At the $5 \%$ level, the proportion of significant $t$-values are 6.52 and 9.09 percent for our spread and depth residual regressions, respectively. These figures are lower than the firm-level NYSE results reported in Chordia, Roll, and Subrahmanyam (2000).
} 
large exchanges. Similarly, the percent of exchanges with positive and significant coefficients is 31.25 percent for small exchanges and 20.00 percent for large exchanges, with medium exchanges in between. Again, in contrast to Table 5's firm-size results where depth commonality increases with size, our exchange-based results show that depth commonality decreases with size.

The size of the exchange, in terms of market capitalization, appears to play a significant role in liquidity transmission. Larger exchanges experience greater spillover effects in the spread dimension, while smaller exchanges experience greater spillover effects in the depth dimension. The main finding in Table 9, however, is that all exchange sizes are susceptible to global commonality in liquidity.

\subsubsection{Global Commonality: Regional Effects}

In Table 10, we apply regression model (4) in order to measure any regional effects on commonality. Similar to our analysis of clusters of firms (by industry) on exchange-level commonality in Table 7, we examine clusters of exchanges (by MSCI region) on global commonality in Table 10. We report separate global and regional coefficients for all world exchanges, developed markets, and emerging markets. For the global (regional) spread results in Panel A, our average contemporaneous coefficient is $0.1231(0.1142)$, and our median coefficient is $0.1135(0.0475)$. The regional contemporaneous coefficients are smaller and less significant than their global counterparts. The regional SUM coefficient is 0.0540 with a $p$-value of 0.243 , while the global SUM coefficient is 0.1852 with a $p$-value of 0.001 . For all exchanges combined, regional commonality plays a smaller (though still significant) role than global commonality. 
We find very different results, however, when we compare the developed market mix of regional versus global commonality to the emerging market mix. The regional component in developed markets is larger and equally significant as the global component. The average global (regional) contemporaneous coefficient is 0.1553 (0.1934), and the median global (regional) coefficient is 0.1553 (0.1873). The global SUM coefficient is larger $(0.2327$ versus 0.1837$)$ but less significant $(p$-values $=0.052$ versus 0.006 ) than the regional SUM coefficient. In contrast, we find only weak evidence for regional commonality in spreads for the emerging markets. The average (median) contemporaneous coefficient is $0.0073(0.0003)$, while the SUM coefficient is negative and insignificant. Developed markets are clearly more affected by changes in regional markets' spreads than emerging markets.

In Panel B, we analyze the separate impacts of global and regional liquidity on depth commonality. For global (regional) depth across all exchanges, we find an average contemporaneous coefficient of 0.0479 (0.0751), and a median coefficient of 0.0344 (0.0398). The regional contemporaneous coefficients are larger and more significant than their global counterparts, although this relation does not hold for the SUM coefficients. Turning to the developed-versus-emerging market coefficients, we find a similar pattern to the spread results in Panel A. The regional source of commonality is larger and more significant than the global source of commonality for the developed markets. The average global contemporaneous coefficient for developed markets is 0.0398 , compared to an average regional coefficient of 0.1234 . Similarly, the median global coefficient is 0.0248 and the median regional coefficient is 0.0546 . While 12 percent of the global coefficients are positive and significant at the five percent level, 32 percent of the 
regional coefficients are positive and significant. The SUM coefficients give mixed results, with a smaller but more significant regional SUM coefficient.

In the emerging markets, the regional source of commonality is smaller than the global source of commonality. The average global contemporaneous coefficient for emerging markets is 0.0580 , compared to an average regional coefficient of 0.0147 ; the median global coefficient is 0.0482 and the median regional coefficient is only 0.0035 . The regional SUM coefficient is negative and insignificant, while the global SUM coefficient is positive and insignificant.

Overall, these results demonstrate that a significant source of commonality in liquidity among exchanges is attributable to regional effects. This regional effect, while significant for spreads and depths across developed and emerging markets, does not fully account for global commonality. That is, there is a separate and distinct source of commonality in liquidity that spills over from exchanges outside of one's MSCI region. For developed markets, a larger portion of commonality in both spreads and depths comes from regional sources. For emerging markets, the global (non-regional) source dominates.

\subsubsection{Global Commonality: Robustness}

In Table 11, we test the robustness of our global commonality results by redefining the global liquidity portfolio. ${ }^{12}$ We rerun the results in Table 8 after excluding the effect of several influential exchanges; NYSE, Nasdaq, the London Stock Exchange, and the Tokyo Stock Exchange. It is possible that the significant global commonality reported in Table 8 is due to the influence of one or more of these large exchanges. We

\footnotetext{
${ }^{12}$ In addition to analyzing various definitions of global liquidity portfolios, we also test the robustness of our global commonality findings after controlling for industry effects. There remains a significant global commonality component in exchange-level liquidity after accounting for industry effects.
} 
select the four largest exchanges in the world; the smallest of the four, the London Stock Exchange, has more than twice the market capitalization of the fifth largest exchange, Euronext Paris.

In Panel A of Table 11, we show that excluding the NYSE, Nasdaq, or London Stock Exchange from the global liquidity portfolio (on an individual basis) has little impact on the magnitude or significance of the average, median, or SUM liquidity coefficients. Excluding the Tokyo Stock Exchange, on the other hand, reduces substantially the magnitude and significance of all liquidity coefficients. After excluding all four exchanges, the average (median) contemporaneous coefficient falls to 0.0987 (0.0864) from a value of $0.1705(0.1745)$ with all exchanges included. We find a similar reduction in the SUM coefficient from 0.2275 to 0.0907 .

Our Panel B results mirror those in Panel A. Although there is more variation in the depth effects of individual exchange exclusions, the largest change from any single exchange continues to be from the Tokyo Stock Exchange. The average (median) contemporaneous coefficient changes from 0.0899 (0.0277) with all exchanges included to $0.0154(0.0488)$ with the four large exchanges excluded. The SUM coefficient changes from 0.0623 to 0.0744 .

In summary, there is a clear reduction in the magnitudes and significance levels for spread commonality after excluding the four largest exchanges. There is some reduction in magnitudes and significance levels for depth commonality as well, although this pattern is not as regular (e.g., the average coefficient increases, while the median coefficient decreases). The main point, however, is that commonality in global liquidity remains significant for both spreads and depths after excluding any influence from the 
largest global exchanges. Global commonality is not driven solely from New York, London, or Tokyo.

\section{Summary and Conclusions}

Previous empirical research finds a common exchange-level component that influences firm-level liquidity, both in terms of bid-ask spreads and depths. Although most of the empirical evidence is restricted to firms trading on a US exchange (Chordia, Roll, and Subrahmanyam (2000), Hasbrouck and Seppi (2001), and Huberman and Halka (2001)), there is limited evidence of commonality on non-US exchanges (Fabre and Frino (2004) and Brockman and Chung (2002)). All previous studies that examine commonality in intraday spreads and depths are single-exchange studies.

Our study contributes to this literature in two primary ways. First, we conduct the first comprehensive investigation of commonality in liquidity using intraday spread and depth data from 47 stock exchanges. Second, we examine the impact of a global liquidity factor on spread and depth commonality. Given the size and scope of our Bloomberg database, we are able to analyze several aspects of commonality that previous, singleexchange studies could not address. These unresolved issues include the pervasiveness of spread and depth commonality, the cross-sectional variation in commonality among exchanges and regions, and the possible existence of a global liquidity factor.

Our empirical results confirm that exchange-level commonality is a widespread phenomenon across the globe. For most exchanges in our sample, the individual firm's bid-ask spreads are significantly influenced by changes in the aggregate market's bid-ask

spreads. Similarly, changes in the individual firm's depths are significantly influenced by 
changes in exchange-level depths. Our cross-sectional results show that the Emerging Asia stock exchanges exhibit exceptionally strong commonality in spreads and depths, while the stock exchanges of Latin American have little, if any, commonality at the exchange level.

We investigate the importance of firm size and industry within each of our 47 stock exchanges. We find that commonality in bid-ask spreads is strongest among small firms, in contrast to previous NYSE-based results. Depth commonality, on the other hand, exhibits a positive and monotonic relation with firm size. Our industry results show that while commonality is significant in each industry, there is considerable variation across industries. Utilities, for example, tend to have less commonality in spreads than other industries, while the basic materials industry is less sensitive to commonality in depths. We also show that industry-level commonality is significantly weaker than exchange-level commonality across our 47 exchanges. This finding is different from previously-reported NYSE results showing that industry effects often dominate exchange effects.

After documenting the pervasive role of commonality within individual stock exchanges, we turn our attention to examining commonality across stock exchanges. We extend the empirical model of Chordia, Roll, and Subrahmanyam (2000) in order to measure the impact of changes in intraday global liquidity on changes in aggregate exchange-level liquidity. Our findings represent the first empirical evidence for the existence of global commonality in spreads and depths.

We find unambiguous support for the hypothesis that commonality in liquidity spills over the national border. Movements in aggregate bid-ask spreads and depths on 
an individual exchange are significantly influenced by movements in spreads and depths at the global scale. The global commonality in liquidity component that we find for spreads and depths is significant in both developed and emerging markets. Comparing the two market categories, we show that developed markets experience more liquidity spillover than emerging market. We also find that liquidity spillover extends beyond the regional level. Again, developed markets appear to be more susceptible to regional commonality influences than emerging markets. For developed markets, a larger portion of depth and spread commonality comes from regional sources. For emerging markets, the non-regional (i.e., global) source dominates. Finally, we show that the total market capitalization of the exchange plays a significant role in the liquidity transmission process.

In summary, our results verify that neither firm- nor exchange-level liquidity can be understood in isolation. Individual firm liquidity is partly determined by an exchangelevel commonality component, and aggregate exchange liquidity is partly determined by a global commonality component. Future research is needed to understand the causes of global liquidity co-movements, as well as to identify the channels through which liquidity changes on one exchange affect the liquidity on another. 


\section{References}

Acharya, V.V., and L.H. Pedersen, 2005, Asset pricing and liquidity risk, Journal of Financial Economics 77, 375-410.

Amihud, Y., and H. Mendelson, 1986, Asset pricing and the bid-ask spread, Journal of Financial Economics 17, 223-249.

Barclay, M., and C. Smith, Jr., 1988, Corporate payout policy: Cash dividends versus open-market repurchases, Journal of Financial Economics 22, 61-82.

Benston, G., and R. Hagerman, 1974, Determinants of bid-ask spreads in the over-thecounter market, Journal of Financial Economics 1, 353-364.

Brennan, M.J., and A. Subrahmanyam, 1996, Market microstructure and asset pricing: On the compensation for illiquidity in stock returns, Journal of Financial Economics 41, 441-464.

Brockman, P., and D.Y. Chung, 1999, An analysis of depth behavior in an electronic, order-driven environment, Journal of Banking and Finance 23, 1861-1886.

Brockman, P., and D.Y. Chung, 2002, Commonality in liquidity: Evidence from an order-driven market structure, Journal of Financial Research 25, 521-539.

Chordia, T., R. Roll, and A. Subrahmanyam, 2000, Commonality in liquidity, Journal of Financial Economics 56, 3-28.

Chordia, T., A. Sarkar, and A. Subrahmanyam, 2005, An empirical analysis of stock and bond market liquidity, Review of Financial Studies 18, 85-129.

Coughenour, J.F., and M.M. Saad, 2004, Common market makers and commonality in liquidity, Journal of Financial Economics 73, 37-69.

Datar, V.T., N.Y. Naik, and R. Radcliffe, 1998, Liquidity and stock returns: An alternative test, Journal of Financial Markets 1, 203-219.

Easley, D., S. Hvidkjaer, and M. O'Hara, 2002, Is information risk a determinant of asset returns?, Journal of Finance 62, 2185-2221.

Fabre, J., and A. Frino, 2004, Commonality in liquidity: Evidence from the Australian Stock Exchange, Accounting and Finance 44, 357-368.

Franz, D.R., R.P. Rao, and N. Tripathy, 1995, Informed trading risk and bid-ask spread changes around open market stock repurchases in the NASDAQ market, Journal of Financial Research 18, 311-327. 
Hasbrouck, J., and D.J. Seppi, 2001, Common factors in prices, order flows, and liquidity, Journal of Financial Economics 59, 383-411.

Huberman, G., and D. Halka, 2001, Systematic liquidity, Journal of Financial Research 24, 161-178.

Noronha, G., A. Sarin, and S. Saudagaran, 1996, Testing for liquidity effects of international dual listings using intraday data, Journal of Banking and Finance 20, 965-983.

Pastor, L., and R. Stambaugh, 2003, Liquidity risk and expected stock returns, Journal of Political Economy 113, 642-685.

Stahel, C.W., 2003, Is there a global liquidity factor? Working Paper, George Mason University.

Stahel, C.W., 2005, Liquidity across developed and emerging markets? Working Paper, George Mason University.

Stoll, H.R., 1978, The supply of dealer services in securities markets, Journal of Finance 33, 1133-1151.

Weinberg, P., 2006, How London can close gap on Wall Street, Financial Times, internet edition, March 29.

Wurgler, J., 2000, Financial markets and the allocation of capital, Journal of Financial Economics 58, 187-214. 
Table 1: Descriptive Statistics

\begin{tabular}{|c|c|c|c|c|c|c|c|c|c|c|}
\hline$\#$ & Exchange & Country & Region & $\begin{array}{l}\text { Number } \\
\text { of Firms }\end{array}$ & $\begin{array}{c}\text { Total } \\
\text { Market } \\
\text { Cap. } \\
\text { (Billion } \\
\text { US\$) }\end{array}$ & $\begin{array}{c}\text { Trading } \\
\text { Volume } \\
\text { (Thousand } \\
\text { US\$) }\end{array}$ & $\begin{array}{c}\text { Number } \\
\text { of } \\
\text { Trades }\end{array}$ & $\begin{array}{c}\text { \% of } \\
\text { Days } \\
\text { with } \\
\text { Trades }\end{array}$ & $\begin{array}{c}\text { Relative } \\
\text { Effective } \\
\text { Spread }\end{array}$ & $\begin{array}{c}\text { Total } \\
\text { Depth in } \\
\text { Value } \\
\text { (US\$) }\end{array}$ \\
\hline 1 & Vienna Stock Exchange & Austria & Europe & 27 & 25.3 & $1,100.1$ & 26 & $94 \%$ & 0.0088 & 120,603 \\
\hline 2 & Copenhagen Stock Ex. & Denmark & Europe & 60 & 81.7 & $2,942.5$ & 91 & $95 \%$ & 0.0093 & 145,705 \\
\hline 3 & Helsinki Stock Exchange & Finland & Europe & 62 & 152.1 & $7,487.1$ & 163 & $94 \%$ & 0.0105 & 146,615 \\
\hline 6 & Frankfurt Stock Exchange & Germany & Europe & 41 & 63.1 & 317.5 & 20 & $82 \%$ & 0.0170 & 35,308 \\
\hline 7 & Athens Stock Exchange & Greece & Europe & 90 & 52.6 & 772.4 & 177 & $99 \%$ & 0.0080 & 130,324 \\
\hline 8 & Irish Stock Exchange & Ireland & Europe & 25 & 56.7 & $5,617.8$ & 36 & $95 \%$ & 0.0122 & 136,911 \\
\hline 9 & Borsa Italiana & Italy & Europe & 121 & 408.6 & $13,786.8$ & 611 & $98 \%$ & 0.0075 & 40,307 \\
\hline 10 & Oslo Stock Exchange & Norway & Europe & 52 & 47.9 & $4,018.2$ & 113 & $92 \%$ & 0.0127 & 140,424 \\
\hline 11 & Euronext Lisbon & Portugal & Europe & 28 & 44.5 & 2,988.2 & 158 & $95 \%$ & 0.0093 & 299,436 \\
\hline 17 & Toronto Stock Exchange & Canada & N-America & 314 & 567.8 & $3,990.7$ & 240 & $97 \%$ & 0.0085 & 585 \\
\hline 18 & American Stock Exchange & USA & N-America & 55 & 40.6 & $2,198.0$ & 169 & $98 \%$ & 0.0115 & 52,798 \\
\hline 19 & NASDAQ & USA & $\mathrm{N}$-America & 1,515 & $2,137.7$ & $6,938.5$ & 688 & $99 \%$ & 0.0060 & 21,243 \\
\hline 20 & New York Stock Exchange & USA & $\mathrm{N}$-America & 1,475 & $9,092.1$ & $20,690.6$ & 729 & $100 \%$ & 0.0041 & 57,880 \\
\hline 21 & Australian Stock Exchange & Australia & Pacific & 199 & 406.5 & $4,276.4$ & 177 & $98 \%$ & 0.0066 & 153,750 \\
\hline 22 & Hong Kong Exchange & Hong Kong & Pacific & 225 & 566.7 & $8,689.9$ & 151 & $96 \%$ & 0.0108 & 606,525 \\
\hline 23 & JASDAQ & Japan & Pacific & 59 & 14.9 & 921.3 & 69 & $93 \%$ & 0.0111 & 43,288 \\
\hline 24 & Osaka Securities Exchange & Japan & Pacific & 70 & 80.1 & $2,568.4$ & 121 & $90 \%$ & 0.0068 & 58,794 \\
\hline 25 & Tokyo Stock Exchange & Japan & Pacific & 1,201 & $1,873.8$ & $4,754.5$ & 164 & $91 \%$ & 0.0049 & 146,937 \\
\hline 26 & New Zealand Exchange & New Zeal. & Pacific & 33 & 65.5 & 869.5 & 32 & $98 \%$ & 0.0076 & N/A \\
\hline 27 & Singapore Exchange Ltd & Singapore & Pacific & 105 & 151.6 & $2,061.0$ & 86 & $98 \%$ & 0.0104 & 381,579 \\
\hline 28 & Shanghai Stock Exchange & China & Asia & 598 & 271.3 & 779.6 & 183 & $98 \%$ & 0.0025 & 13,202 \\
\hline
\end{tabular}


Table 1: Descriptive Statistics (Continued)

\begin{tabular}{|c|c|c|c|c|c|c|c|c|c|c|}
\hline$\#$ & Exchange & Country & Region & $\begin{array}{l}\text { Number } \\
\text { of Firms }\end{array}$ & $\begin{array}{c}\text { Total } \\
\text { Market } \\
\text { Cap. } \\
\text { (Billion } \\
\text { US\$) }\end{array}$ & $\begin{array}{c}\text { Trading } \\
\text { Volume } \\
\text { (Thousand } \\
\text { US\$) }\end{array}$ & $\begin{array}{c}\text { Number } \\
\text { of } \\
\text { Trades }\end{array}$ & $\begin{array}{c}\% \text { of } \\
\text { Days } \\
\text { with } \\
\text { Trades }\end{array}$ & $\begin{array}{c}\text { Relative } \\
\text { Effective } \\
\text { Spread }\end{array}$ & $\begin{array}{c}\text { Total } \\
\text { Depth in } \\
\text { Value } \\
\text { (US\$) }\end{array}$ \\
\hline 31 & National Stock Ex. of India & India & Asia & 111 & 102.2 & $1,512.1$ & 501 & $98 \%$ & 0.0025 & 3,425 \\
\hline 32 & Jakarta Stock Exchange & Indonesia & Asia & 32 & 25.4 & $1,199.5$ & 137 & $96 \%$ & 0.0295 & 469,623 \\
\hline 33 & KOSDAQ Market Division & Korea & Asia & 16 & 6.8 & $6,489.1$ & 1,697 & $100 \%$ & 0.0040 & 54,332 \\
\hline 34 & Korea Exchange & Korea & Asia & 140 & 176.2 & $6,430.0$ & 1,037 & $99 \%$ & 0.0039 & 111,408 \\
\hline 35 & Bursa Malaysia & Malaysia & Asia & 160 & 106.4 & 606.5 & 60 & $97 \%$ & 0.0094 & 92,281 \\
\hline 36 & Philippine Stock Exchange & Philippines & Asia & 27 & 30.4 & 290.3 & 44 & $93 \%$ & 0.0183 & 70,642 \\
\hline 37 & Taiwan Stock Exchange & Taiwan & Asia & 289 & 212.4 & $5,763.2$ & 221 & $99 \%$ & 0.0053 & 294,005 \\
\hline 38 & Stock Ex. of Thailand & Thailand & Asia & 80 & 49.5 & $2,202.8$ & 203 & $96 \%$ & 0.0094 & 193,232 \\
\hline 39 & Budapest Stock Exchange & Hungary & Europe-MEA & 13 & 12.0 & $1,745.2$ & 127 & $96 \%$ & 0.0124 & 27,841 \\
\hline 40 & Warsaw Stock Exchange & Poland & Europe-MEA & 26 & 22.9 & 987.1 & 156 & $96 \%$ & 0.0084 & 49,190 \\
\hline 41 & Johannesburg Stock Ex. & South Africa & Europe-MEA & 74 & 145.9 & 717.2 & 4 & $82 \%$ & 0.0100 & 149,975 \\
\hline 42 & Istanbul Stock Exchange & Turkey & Europe-MEA & 59 & 39.2 & 5.6 & 883 & $100 \%$ & 0.0098 & 523 \\
\hline 43 & Buenos Aires Stock Ex. & Argentina & Latin America & 19 & 87.4 & 456.6 & 103 & $97 \%$ & 0.0116 & 23,169 \\
\hline 44 & Sao Paulo Stock Exchange & Brazil & Latin America & 45 & 90.1 & 649.9 & 66 & $86 \%$ & 0.0238 & 31,987 \\
\hline 45 & Santiago Stock Exchange & Chile & Latin America & 43 & 42.4 & 508.2 & 19 & $85 \%$ & 0.0180 & 25,770 \\
\hline 46 & Mexican Stock Exchange & Mexico & Latin America & 39 & 146.4 & $2,318.3$ & 84 & $93 \%$ & 0.0124 & 118,985 \\
\hline \multirow[t]{2}{*}{47} & Lima Stock Exchange & Peru & Latin America & 13 & 10.0 & 103.0 & 10 & $86 \%$ & 0.0276 & 235,586 \\
\hline & All Exchanges Combined & All & All & 9,427 & $22,382.4$ & 7,593.6 & 378 & $96 \%$ & 0.0067 & 105,646 \\
\hline
\end{tabular}

Note: This table presents for each sample exchange, the name, country, region (MSCI), number of listed firms, total market capitalization in billions of US\$, and several descriptive statistics computed over the period October 1, 2002 to June 30, 2004. The MSCI regions are Europe (Developed Markets - Europe), NAmerica (Developed Markets - North America), Pacific (Developed Markets - Pacific), Asia (Emerging Markets - Asia), Europe-MEA (Emerging Markets Europe, Middle East, and Africa), and Latin America (Emerging Markets - Latin America). Trading Volume (Thousand US\$) is the average value of shares traded per day and per firm measured in thousands of US\$, Number of Trades is the average number of transactions per day and per firm, \% of Days with Trades is the percent of trading days with at least one transaction, Relative Effective Spread is the effective spread (i.e., twice the absolute trading price deviation from the bid-ask midpoint) divided by the bid-ask midpoint, and Total Depth in Value is the number of shares at the bid and ask multiplied by their respective prices converted in US\$. Each trading activity and liquidity measure is averaged across day for each firm, and then their mean is computed across firms. 
Table 2: Exchange-Level Commonality - Spread Results

\begin{tabular}{|c|c|c|c|c|c|c|c|c|c|}
\hline & & $\begin{array}{l}\text { Average } \\
\text { Coef. }\end{array}$ & $\begin{array}{l}\text { Median } \\
\text { Coef. }\end{array}$ & $\begin{array}{c}\text { \% Firms } \\
\text { with }>0 \\
\text { Coef. } \\
\text { Signif. 5\% } \\
\text { Level }\end{array}$ & $\begin{array}{c}\text { \% Firms } \\
\text { with }>0 \\
\text { Coef. Not } \\
\text { Signif. 5\% } \\
\text { Level }\end{array}$ & $\begin{array}{c}\% \text { Firms } \\
\text { with }<0 \\
\text { Coef. Not } \\
\text { Signif. 5\% } \\
\text { Level }\end{array}$ & $\begin{array}{c}\text { \% Firms } \\
\text { with }<0 \\
\text { Coef. } \\
\text { Signif. 5\% } \\
\text { Level }\end{array}$ & $\begin{array}{c}\text { Median } \\
\text { SUM }_{E} \\
\text { Coef. }\end{array}$ & $\begin{array}{c}\text { p-value } \\
\text { (Median } \\
\text { SUM }_{E} \\
\text { Coef.) }\end{array}$ \\
\hline & Europe & & & & & & & & \\
\hline 1 & Vienna Stock Exchange & 0.2041 & 0.2464 & $29.63 \%$ & $40.74 \%$ & $22.22 \%$ & $7.41 \%$ & 0.1361 & 0.248 \\
\hline 2 & Copenhagen Stock Ex. & 0.1958 & 0.1918 & $16.67 \%$ & $58.33 \%$ & $25.00 \%$ & $0.00 \%$ & 0.2456 & 0.006 \\
\hline 3 & Helsinki Stock Exchange & 0.1673 & 0.0885 & $12.90 \%$ & $58.06 \%$ & $27.42 \%$ & $1.61 \%$ & 0.0344 & 0.374 \\
\hline 4 & Euronext Paris & 0.2115 & 0.1347 & $7.73 \%$ & $60.00 \%$ & $31.36 \%$ & $0.91 \%$ & 0.1663 & 0.000 \\
\hline 5 & Deutsche Boerse & 0.2065 & 0.2484 & $25.56 \%$ & $53.38 \%$ & $21.05 \%$ & $0.00 \%$ & 0.3845 & 0.000 \\
\hline 6 & Frankfurt Stock Exchange & 0.2871 & 0.0696 & $5.13 \%$ & $48.72 \%$ & $43.59 \%$ & $2.56 \%$ & 0.0084 & 1.000 \\
\hline 7 & Athens Stock Exchange & 0.2054 & 0.2099 & $23.33 \%$ & $64.44 \%$ & $11.11 \%$ & $1.11 \%$ & 0.1166 & 0.001 \\
\hline 8 & Irish Stock Exchange & 0.2409 & 0.2274 & $52.00 \%$ & $36.00 \%$ & $12.00 \%$ & $0.00 \%$ & 0.2886 & 0.000 \\
\hline 9 & Borsa Italiana & 0.0614 & 0.0198 & $5.79 \%$ & $57.02 \%$ & $36.36 \%$ & $0.83 \%$ & 0.0318 & 0.001 \\
\hline 10 & Oslo Stock Exchange & 0.1075 & 0.0372 & $13.46 \%$ & $42.31 \%$ & $42.31 \%$ & $1.92 \%$ & 0.0098 & 0.489 \\
\hline 11 & Euronext Lisbon & 0.2687 & 0.1596 & $25.00 \%$ & $60.71 \%$ & $14.29 \%$ & $0.00 \%$ & 0.1381 & 0.000 \\
\hline 12 & Spanish Cont. Market & 0.1337 & 0.1845 & $30.59 \%$ & $54.12 \%$ & $15.29 \%$ & $0.00 \%$ & 0.1821 & 0.000 \\
\hline 13 & Stockholm Stock Exchange & 0.0644 & 0.0391 & $10.26 \%$ & $54.70 \%$ & $31.62 \%$ & $3.42 \%$ & 0.0544 & 0.042 \\
\hline 14 & Swiss Exchange & 0.1817 & 0.2195 & $8.49 \%$ & $65.09 \%$ & $25.47 \%$ & $0.94 \%$ & 0.2602 & 0.003 \\
\hline 15 & Virt-X & 0.3384 & 0.3283 & $80.77 \%$ & $15.38 \%$ & $3.85 \%$ & $0.00 \%$ & 0.4916 & 0.000 \\
\hline 16 & London Stock Exchange & 1.2183 & 1.1251 & $42.07 \%$ & $47.42 \%$ & $9.96 \%$ & $0.55 \%$ & 1.2318 & 0.000 \\
\hline 17 & $\begin{array}{c}\text { North America } \\
\text { Toronto Stock Exchange }\end{array}$ & 0.7902 & 0.6675 & $57.56 \%$ & $35.69 \%$ & $6.75 \%$ & $0.00 \%$ & 0.7724 & 0.000 \\
\hline 18 & American Stock Exchange & 0.2900 & 0.0665 & $22.64 \%$ & $50.94 \%$ & $26.42 \%$ & $0.00 \%$ & 0.0295 & 0.419 \\
\hline 19 & NASDAQ & 0.9248 & 0.6995 & $72.98 \%$ & $24.30 \%$ & $2.72 \%$ & $0.00 \%$ & 0.6661 & 0.000 \\
\hline 20 & New York Stock Exchange & 0.3550 & 0.2022 & $20.73 \%$ & $55.46 \%$ & $22.86 \%$ & $0.96 \%$ & 0.1796 & 0.000 \\
\hline 21 & $\begin{array}{c}\text { Pacific } \\
\text { Australian Stock Exchange }\end{array}$ & 0.5880 & 0.3581 & $58.08 \%$ & $33.84 \%$ & $8.08 \%$ & $0.00 \%$ & 0.2629 & 0.000 \\
\hline 22 & Hong Kong Exchange & 0.1662 & 0.0703 & $8.89 \%$ & $59.56 \%$ & $28.44 \%$ & $3.11 \%$ & 0.0594 & 0.016 \\
\hline 23 & JASDAQ & 0.1229 & 0.0515 & $1.69 \%$ & $59.32 \%$ & $37.29 \%$ & $1.69 \%$ & 0.0612 & 0.795 \\
\hline 24 & Osaka Securities Exchange & 0.2336 & 0.1677 & $17.14 \%$ & $61.43 \%$ & $17.14 \%$ & $4.29 \%$ & 0.1588 & 0.006 \\
\hline 25 & Tokyo Stock Exchange & 0.8011 & 0.5388 & $64.15 \%$ & $29.15 \%$ & $6.62 \%$ & $0.08 \%$ & 0.5187 & 0.000 \\
\hline 26 & New Zealand Exchange & 0.1671 & 0.1139 & $12.12 \%$ & $57.58 \%$ & $30.30 \%$ & $0.00 \%$ & 0.1089 & 0.487 \\
\hline 27 & Singapore Exchange Ltd & 0.1341 & 0.0813 & $15.24 \%$ & $56.19 \%$ & $23.81 \%$ & $4.76 \%$ & 0.1140 & 0.006 \\
\hline
\end{tabular}


Table 2: Exchange-Level Commonality - Spread Results (Continued)

\begin{tabular}{|c|c|c|c|c|c|c|c|c|c|}
\hline & & $\begin{array}{c}\text { Average } \\
\text { Coef. }\end{array}$ & $\begin{array}{c}\text { Median } \\
\text { Coef. }\end{array}$ & $\begin{array}{c}\% \text { Firms } \\
\text { with }>0 \\
\text { Coef. } \\
\text { Signif. 5\% } \\
\text { Level }\end{array}$ & $\begin{array}{c}\% \text { Firms } \\
\text { with }>0 \\
\text { Coef. Not } \\
\text { Signif. 5\% } \\
\text { Level }\end{array}$ & $\begin{array}{c}\% \text { Firms } \\
\text { with }<0 \\
\text { Coef. Not } \\
\text { Signif. 5\% } \\
\text { Level }\end{array}$ & $\begin{array}{c}\% \text { Firms } \\
\text { with }<0 \\
\text { Coef. } \\
\text { Signif. 5\% } \\
\text { Level }\end{array}$ & $\begin{array}{c}\text { Median } \\
\text { SUM }_{E} \\
\text { Coef. }\end{array}$ & $\begin{array}{c}\text { p-value } \\
\text { (Median } \\
\text { SUM }_{E} \\
\text { Coef.) }\end{array}$ \\
\hline 28 & Emerging - Asia & 07586 & O 7273 & $82610 /$ & $14380 /$ & 3010 & $0 \Omega 0 \%$ & 06746 & مח0 \\
\hline $\begin{array}{l}28 \\
29\end{array}$ & Shenzhen Stock Exchange & $\begin{array}{l}0.7580 \\
0.7472\end{array}$ & $\begin{array}{l}0.1213 \\
0.6996\end{array}$ & $\begin{array}{l}82.01 \% \\
86.91 \%\end{array}$ & $\begin{array}{l}14.38 \% \\
11.20 \%\end{array}$ & $\begin{array}{l}3.01 \% \\
1.90 \%\end{array}$ & $\begin{array}{l}0.00 \% \\
0.00 \%\end{array}$ & $\begin{array}{l}0.6 / 46 \\
0.6492\end{array}$ & $\begin{array}{l}0.000 \\
0.000\end{array}$ \\
\hline 30 & Bombay Stock Exchange & 0.5414 & 0.5608 & $80.67 \%$ & $16.81 \%$ & $2.52 \%$ & $0.00 \%$ & 0.8396 & 0.000 \\
\hline 31 & National Stock Ex. of India & 0.6590 & 0.6679 & $91.89 \%$ & $8.11 \%$ & $0.00 \%$ & $0.00 \%$ & 0.7834 & 0.000 \\
\hline 32 & Jakarta Stock Exchange & 0.2293 & 0.0571 & $18.75 \%$ & $53.13 \%$ & $21.88 \%$ & $6.25 \%$ & 0.0431 & 0.597 \\
\hline 33 & KOSDAQ Market Division & 0.1620 & 0.1339 & $62.50 \%$ & $31.25 \%$ & $6.25 \%$ & $0.00 \%$ & 0.1551 & 0.021 \\
\hline 34 & Korea Exchange & 0.4534 & 0.3993 & $63.57 \%$ & $31.43 \%$ & $5.00 \%$ & $0.00 \%$ & 0.3597 & 0.000 \\
\hline 35 & Bursa Malaysia & 0.3290 & 0.1755 & $22.50 \%$ & $55.63 \%$ & $21.25 \%$ & $0.63 \%$ & 0.2371 & 0.000 \\
\hline 36 & Philippine Stock Exchange & 0.2803 & 0.0121 & $11.11 \%$ & $48.15 \%$ & $37.04 \%$ & $3.70 \%$ & 0.0477 & 0.248 \\
\hline 37 & Taiwan Stock Exchange & 0.9136 & 0.8789 & $84.78 \%$ & $13.15 \%$ & $1.73 \%$ & $0.35 \%$ & 0.8345 & 0.000 \\
\hline 38 & Stock Ex. of Thailand & -0.0031 & 0.0150 & $7.50 \%$ & $61.25 \%$ & $30.00 \%$ & $1.25 \%$ & 0.0093 & 0.314 \\
\hline & Emerging - Europe MEA & & & & & & & & \\
\hline 39 & Budapest Stock Exchange & 0.0455 & 0.0322 & $0.00 \%$ & $69.23 \%$ & $23.08 \%$ & $7.69 \%$ & 0.0648 & 0.581 \\
\hline 40 & Warsaw Stock Exchange & 0.2055 & 0.1287 & $11.54 \%$ & $73.08 \%$ & $15.38 \%$ & $0.00 \%$ & 0.1365 & 0.076 \\
\hline 41 & Johannesburg Stock Ex. & 0.0792 & 0.2116 & $9.59 \%$ & $54.79 \%$ & $34.25 \%$ & $1.37 \%$ & 0.2936 & 0.416 \\
\hline 42 & Istanbul Stock Exchange & 0.4611 & 0.4747 & $83.05 \%$ & $15.25 \%$ & $1.69 \%$ & $0.00 \%$ & 0.7464 & 0.000 \\
\hline & Emerging - Latin America & & & & & & & & \\
\hline 43 & Buenos Aires Stock Ex. & -0.1441 & 0.0077 & $5.26 \%$ & $47.37 \%$ & $36.84 \%$ & $10.53 \%$ & 0.0160 & 1.000 \\
\hline 44 & Sao Paulo Stock Exchange & -0.0599 & 0.0670 & $6.98 \%$ & $51.16 \%$ & $39.53 \%$ & $2.33 \%$ & 0.0376 & 1.000 \\
\hline 45 & Santiago Stock Exchange & -0.1196 & -0.1123 & $2.44 \%$ & $31.71 \%$ & $63.41 \%$ & $2.44 \%$ & -0.1415 & 0.222 \\
\hline 46 & Mexican Stock Exchange & 0.1013 & 0.0506 & $7.69 \%$ & $61.54 \%$ & $30.77 \%$ & $0.00 \%$ & 0.0213 & 0.337 \\
\hline 47 & Lima Stock Exchange & 0.1774 & 0.0003 & $7.69 \%$ & $46.15 \%$ & $46.15 \%$ & $0.00 \%$ & 0.0940 & 0.581 \\
\hline
\end{tabular}

Note: Firm-by-firm $(9,427)$ time-series regressions of liquidity measures are estimated using:

$$
\Delta_{\text {Liquidity }_{F, t}}=\alpha+\beta_{1} \text { LLiquidity }_{E, t}+\beta_{2} \text { LLiquidity }_{E, t+1}+\beta_{3} \text { LLiquidity }_{E, t-1}+\delta_{1} \text { Return }_{E, t}+\delta_{2} \text { Return }_{E, t+1}+\delta_{3} \text { Return }_{E, t-1}+\delta_{4} \Delta \text { Volatility }_{F, t}+\varepsilon_{F, t}
$$

Liquidity $_{F, t}$ is the relative effective spread of firm $F$ on day $t$. Liquidity ${ }_{E, t}$ is the exchange-level liquidity index and Return $n_{E, t}$ is the exchange-level return computed on day $t$ using an equal-weighted average of the liquidity measure and return, respectively, for all firms trading on the same exchange, except firm $F$. Volatility ${ }_{F, t}$ is the return volatility for firm $F$ on day $t$ and is measured as the squared return for the day. The symbol $\Delta$ preceding a variable name denotes a proportional change in the variable across successive trading days. We present the average and median coefficient estimate of the exchange-level liquidity beta $\beta_{1}$, along with 
the percent of firms for which $\beta_{1}$ is positive and significant at the $5 \%$ confidence level (t-statistic $>1.645$ ), positive and not significant at the $5 \%$ confidence level, negative and not significant at the 5\% confidence level, and negative and significant at the $5 \%$ confidence level, respectively. We report in the last two columns the median of the sum of the concurrent, lead and lag coefficient estimates $\left(\mathrm{SUM}_{E}=\beta_{1}+\beta_{2}+\beta_{3}\right)$ and the $\mathrm{p}$-value of a sign test testing whether Median $\left(\mathrm{SUM}_{E}\right)=0$. 
Table 3: Exchange-Level Commonality - Depth Results

\begin{tabular}{|c|c|c|c|c|c|c|c|c|c|}
\hline & & $\begin{array}{c}\text { Average } \\
\text { Coef. }\end{array}$ & $\begin{array}{l}\text { Median } \\
\text { Coef. }\end{array}$ & $\begin{array}{c}\text { \% Firms } \\
\text { with >0 } \\
\text { Coef. } \\
\text { Signif. 5\% } \\
\text { Level }\end{array}$ & $\begin{array}{c}\text { \% Firms } \\
\text { with >0 } \\
\text { Coef. Not } \\
\text { Signif. 5\% } \\
\text { Level }\end{array}$ & $\begin{array}{c}\text { \% Firms } \\
\text { with <0 } \\
\text { Coef. Not } \\
\text { Signif. 5\% } \\
\text { Level }\end{array}$ & $\begin{array}{c}\text { \% Firms } \\
\text { with }<0 \\
\text { Coef. } \\
\text { Signif. 5\% } \\
\text { Level }\end{array}$ & $\begin{array}{c}\text { Median } \\
\text { SUM }_{E} \\
\text { Coef. }\end{array}$ & $\begin{array}{l}\text { p-value } \\
\text { (Median } \\
\text { SUM }_{E} \\
\text { Coef.) }\end{array}$ \\
\hline \multicolumn{10}{|c|}{ Europe } \\
\hline 1 & Vienna Stock Exchange & 0.2112 & 0.2036 & $22.22 \%$ & $59.26 \%$ & $18.52 \%$ & $0.00 \%$ & 0.3353 & 0.019 \\
\hline 2 & Copenhagen Stock Ex. & 0.0162 & 0.1236 & $16.67 \%$ & $45.00 \%$ & $35.00 \%$ & $3.33 \%$ & 0.0289 & 0.519 \\
\hline 3 & Helsinki Stock Exchange & -0.0068 & 0.0007 & $4.84 \%$ & $46.77 \%$ & $48.39 \%$ & $0.00 \%$ & -0.0154 & 0.098 \\
\hline 4 & Euronext Paris & 0.0269 & 0.0021 & $8.60 \%$ & $44.34 \%$ & $47.06 \%$ & $0.00 \%$ & -0.0156 & 0.031 \\
\hline 5 & Deutsche Boerse & 0.2082 & 0.2059 & $21.19 \%$ & $52.54 \%$ & $26.27 \%$ & $0.00 \%$ & 0.1663 & 0.342 \\
\hline 6 & Frankfurt Stock Exchange & 0.4283 & 0.0631 & $20.00 \%$ & $46.67 \%$ & $33.33 \%$ & $0.00 \%$ & 0.0205 & 0.000 \\
\hline 7 & Athens Stock Exchange & -0.0066 & -0.0028 & $4.44 \%$ & $40.00 \%$ & $55.56 \%$ & $0.00 \%$ & -0.0074 & 0.015 \\
\hline 8 & Irish Stock Exchange & 0.1832 & 0.1800 & $12.00 \%$ & $64.00 \%$ & $24.00 \%$ & $0.00 \%$ & 0.2481 & 0.001 \\
\hline 9 & Borsa Italiana & 0.3874 & 0.2955 & $25.21 \%$ & $54.62 \%$ & $20.17 \%$ & $0.00 \%$ & 0.2976 & 0.001 \\
\hline 10 & Oslo Stock Exchange & 0.1832 & 0.2495 & $30.77 \%$ & $48.08 \%$ & $21.15 \%$ & $0.00 \%$ & 0.1893 & 0.000 \\
\hline 11 & Euronext Lisbon & 0.3709 & 0.2937 & $37.04 \%$ & $51.85 \%$ & $11.11 \%$ & $0.00 \%$ & 0.1277 & 0.087 \\
\hline 12 & Spanish Cont. Market & 3.5136 & 1.3870 & $72.00 \%$ & $16.00 \%$ & $12.00 \%$ & $0.00 \%$ & 1.5532 & 0.000 \\
\hline 13 & Stockholm Stock Exchange & 0.2392 & 0.3424 & $43.97 \%$ & $41.38 \%$ & $12.93 \%$ & $1.72 \%$ & 0.4571 & 0.000 \\
\hline 14 & Swiss Exchange & -0.0185 & 0.1017 & $5.77 \%$ & $52.88 \%$ & $39.42 \%$ & $1.92 \%$ & -0.0962 & 0.382 \\
\hline 15 & Virt-X & 0.3195 & 0.3243 & $73.08 \%$ & $23.08 \%$ & $3.85 \%$ & $0.00 \%$ & 0.2450 & 0.003 \\
\hline \multirow[t]{2}{*}{16} & London Stock Exchange & N/A & $\mathrm{N} / \mathrm{A}$ & N/A & N/A & $\mathrm{N} / \mathrm{A}$ & $\mathrm{N} / \mathrm{A}$ & $\mathrm{N} / \mathrm{A}$ & N/A \\
\hline & North America & & & & & & & & \\
\hline 17 & Toronto Stock Exchange & 0.8905 & 0.8420 & $54.31 \%$ & $35.14 \%$ & $9.90 \%$ & $0.64 \%$ & 1.0900 & 0.000 \\
\hline 18 & American Stock Exchange & 0.0110 & -0.0061 & $9.09 \%$ & $36.36 \%$ & $54.55 \%$ & $0.00 \%$ & -0.0386 & 0.590 \\
\hline 19 & NASDAQ & 0.8254 & 0.7291 & $28.68 \%$ & $53.58 \%$ & $17.42 \%$ & $0.33 \%$ & 0.7468 & 0.000 \\
\hline \multirow[t]{2}{*}{20} & New York Stock Exchange & 0.7703 & 0.7951 & $47.43 \%$ & $41.19 \%$ & $11.10 \%$ & $0.27 \%$ & 0.8407 & 0.000 \\
\hline & Pacific & & & & & & & & \\
\hline 21 & Australian Stock Exchange & 0.2654 & 0.1305 & $25.51 \%$ & $49.49 \%$ & $22.96 \%$ & $2.04 \%$ & 0.0291 & 0.023 \\
\hline 22 & Hong Kong Exchange & 0.3208 & 0.3558 & $48.44 \%$ & $37.78 \%$ & $12.89 \%$ & $0.89 \%$ & 0.3799 & 0.000 \\
\hline 23 & JASDAQ & 0.1310 & 0.0512 & $8.47 \%$ & $57.63 \%$ & $33.90 \%$ & $0.00 \%$ & 0.0872 & 0.067 \\
\hline 24 & Osaka Securities Exchange & 0.0520 & 0.0359 & $10.14 \%$ & $50.72 \%$ & $39.13 \%$ & $0.00 \%$ & 0.1142 & 0.120 \\
\hline 25 & Tokyo Stock Exchange & 0.5136 & 0.5047 & $39.95 \%$ & $47.71 \%$ & $12.01 \%$ & $0.33 \%$ & 0.5321 & 0.000 \\
\hline 26 & New Zealand Exchange & $\mathrm{N} / \mathrm{A}$ & $\mathrm{N} / \mathrm{A}$ & $\mathrm{N} / \mathrm{A}$ & $\mathrm{N} / \mathrm{A}$ & $\mathrm{N} / \mathrm{A}$ & $\mathrm{N} / \mathrm{A}$ & $\mathrm{N} / \mathrm{A}$ & N/A \\
\hline 27 & Singapore Exchange Ltd & 0.3126 & 0.2785 & $40.95 \%$ & $48.57 \%$ & $10.48 \%$ & $0.00 \%$ & 0.3107 & 0.000 \\
\hline
\end{tabular}


Table 3: Exchange-Level Commonality - Depth Results (Continued)

\begin{tabular}{|c|c|c|c|c|c|c|c|c|c|}
\hline & & $\begin{array}{c}\text { Average } \\
\text { Coef. }\end{array}$ & $\begin{array}{c}\text { Median } \\
\text { Coef. }\end{array}$ & $\begin{array}{c}\% \text { Firms } \\
\text { with }>0 \\
\text { Coef. } \\
\text { Signif. 5\% } \\
\text { Level }\end{array}$ & $\begin{array}{c}\% \text { Firms } \\
\text { with }>0 \\
\text { Coef. Not } \\
\text { Signif. 5\% } \\
\text { Level }\end{array}$ & $\begin{array}{c}\% \text { Firms } \\
\text { with }<0 \\
\text { Coef. Not } \\
\text { Signif. 5\% } \\
\text { Level }\end{array}$ & $\begin{array}{c}\% \text { Firms } \\
\text { with }<0 \\
\text { Coef. } \\
\text { Signif. 5\% } \\
\text { Level }\end{array}$ & $\begin{array}{c}\text { Median } \\
\text { SUM }_{E} \\
\text { Coef. }\end{array}$ & $\begin{array}{c}\text { p-value } \\
\text { (Median } \\
\text { SUM }_{E} \\
\text { Coef.) }\end{array}$ \\
\hline 28 & Emerging - Asia & 07824 & 07327 & $6780 \%$ & $2726 \%$ & $485 \%$ & $000 \%$ & 08356 & 0000 \\
\hline $\begin{array}{l}28 \\
29\end{array}$ & Shenzhen Stock Exchange & 0.6710 & $\begin{array}{l}0.1322 \\
0.6546\end{array}$ & $58.06 \%$ & $37.00 \%$ & $\begin{array}{l}4.85 \% \\
4.74 \%\end{array}$ & $\begin{array}{l}0.00 \% \\
0.19 \%\end{array}$ & $\begin{array}{l}0.8356 \\
0.7436\end{array}$ & $\begin{array}{l}0.000 \\
0.000\end{array}$ \\
\hline 30 & Bombay Stock Exchange & 0.4048 & 0.3514 & $22.88 \%$ & $55.08 \%$ & $21.19 \%$ & $0.85 \%$ & 0.4325 & 0.000 \\
\hline 31 & National Stock Ex. of India & 0.5089 & 0.3833 & $31.82 \%$ & $55.45 \%$ & $11.82 \%$ & $0.91 \%$ & 0.4998 & 0.000 \\
\hline 32 & Jakarta Stock Exchange & 0.3030 & 0.3302 & $48.28 \%$ & $44.83 \%$ & $3.45 \%$ & $3.45 \%$ & 0.2391 & 0.215 \\
\hline 33 & KOSDAQ Market Division & 0.2610 & 0.3055 & $50.00 \%$ & $31.25 \%$ & $18.75 \%$ & $0.00 \%$ & 0.3990 & 0.021 \\
\hline 34 & Korea Exchange & 0.1680 & 0.1747 & $30.71 \%$ & $51.43 \%$ & $17.86 \%$ & $0.00 \%$ & 0.1204 & 0.001 \\
\hline 35 & Bursa Malaysia & 1.4947 & 1.0664 & $97.50 \%$ & $1.87 \%$ & $0.63 \%$ & $0.00 \%$ & 1.0759 & 0.000 \\
\hline 36 & Philippine Stock Exchange & 0.2937 & 0.3128 & $37.04 \%$ & $48.15 \%$ & $14.81 \%$ & $0.00 \%$ & 0.3401 & 0.000 \\
\hline 37 & Taiwan Stock Exchange & 0.5963 & 0.5566 & $71.63 \%$ & $25.26 \%$ & $3.11 \%$ & $0.00 \%$ & 0.5997 & 0.000 \\
\hline 38 & Stock Ex. of Thailand & 0.7348 & 0.7574 & $72.50 \%$ & $21.25 \%$ & $6.25 \%$ & $0.00 \%$ & 0.8965 & 0.000 \\
\hline & Emerging - Europe MEA & & & & & & & & \\
\hline 39 & Budapest Stock Exchange & 0.1861 & 0.2313 & $46.15 \%$ & $23.08 \%$ & $30.77 \%$ & $0.00 \%$ & 0.4057 & 0.267 \\
\hline 40 & Warsaw Stock Exchange & 0.2139 & 0.2790 & $42.31 \%$ & $38.46 \%$ & $15.38 \%$ & $3.85 \%$ & 0.1974 & 0.169 \\
\hline 41 & Johannesburg Stock Ex. & 1.0312 & 0.8344 & $35.82 \%$ & $43.28 \%$ & $19.40 \%$ & $1.49 \%$ & 1.2190 & 0.047 \\
\hline 42 & Istanbul Stock Exchange & 0.8078 & 0.8865 & $88.14 \%$ & $8.47 \%$ & $3.39 \%$ & $0.00 \%$ & 0.8645 & 0.000 \\
\hline & Emerging - Latin America & & & & & & & & \\
\hline 43 & Buenos Aires Stock Ex. & 0.3334 & 0.3094 & $47.37 \%$ & $52.63 \%$ & $0.00 \%$ & $0.00 \%$ & 0.5166 & 0.001 \\
\hline 44 & Sao Paulo Stock Exchange & 0.3434 & -0.0212 & $6.67 \%$ & $35.56 \%$ & $57.78 \%$ & $0.00 \%$ & 0.0025 & 0.766 \\
\hline 45 & Santiago Stock Exchange & -0.0468 & 0.1577 & $17.07 \%$ & $41.46 \%$ & $39.02 \%$ & $2.44 \%$ & 0.0800 & 0.761 \\
\hline 46 & Mexican Stock Exchange & -0.0297 & -0.0054 & $5.13 \%$ & $33.33 \%$ & $61.54 \%$ & $0.00 \%$ & -0.0149 & 0.108 \\
\hline 47 & Lima Stock Exchange & -0.0016 & -0.0017 & $7.69 \%$ & $30.77 \%$ & $61.54 \%$ & $0.00 \%$ & 0.0004 & 1.000 \\
\hline
\end{tabular}

Note: Firm-by-firm $(9,427)$ time-series regressions of liquidity measures are estimated using:

$$
\Delta_{\text {Liquidity }}^{F, t}=\alpha+\beta_{1} \text { LLiquidity }_{E, t}+\beta_{2} \text { LLiquidity }_{E, t+1}+\beta_{3} \text { LLiquidity }_{E, t-1}+\delta_{1} \text { Return }_{E, t}+\delta_{2} \text { Return }_{E, t+1}+\delta_{3} \text { Return }_{E, t-1}+\delta_{4} \Delta \text { Volatility }_{F, t}+\varepsilon_{F, t}
$$

Liquidity $_{F, t}$ is the total depth in value of firm $F$ on day $t$. Liquidity L $_{E, t}$ is the exchange-level liquidity index and Return $n_{E, t}$ is the exchange-level return computed on day $t$ using an equal-weighted average of the liquidity measure and return, respectively, for all firms trading on the same exchange, except firm $F$. Volatility ${ }_{F, t}$ is the return volatility for firm $F$ on day $t$ and is measured as the squared return for the day. The symbol $\Delta$ preceding a variable name denotes a proportional change in the variable across successive trading days. We present the average and median coefficient estimate of the exchange-level liquidity beta $\beta_{1}$, along with the 
percent of firms for which $\beta_{1}$ is positive and significant at the $5 \%$ confidence level (t-statistic $>1.645$ ), positive and not significant at the $5 \%$ confidence level, negative and not significant at the $5 \%$ confidence level, and negative and significant at the $5 \%$ confidence level, respectively. We report in the last two columns the median of the sum of the concurrent, lead and lag coefficient estimates $\left(\mathrm{SUM}_{E}=\beta_{1}+\beta_{2}+\beta_{3}\right)$ and the $\mathrm{p}$-value of a sign test testing whether Median ( $\left.\mathrm{SUM}_{E}\right)$ $=0$. 
Table 4: Exchange-Level Commonality

\begin{tabular}{|c|c|c|c|c|c|c|c|c|}
\hline & $\begin{array}{c}\text { Average } \\
\text { Coef. }\end{array}$ & $\begin{array}{l}\text { Median } \\
\text { Coef. }\end{array}$ & $\begin{array}{c}\text { \% Firms } \\
\text { with >0 } \\
\text { Coefficient } \\
\text { Signif. 5\% } \\
\text { Level }\end{array}$ & $\begin{array}{c}\text { \% Firms } \\
\text { with >0 } \\
\text { Coeff. Not } \\
\text { Signif. 5\% } \\
\text { Level }\end{array}$ & $\begin{array}{c}\text { \% Firms } \\
\text { with <0 } \\
\text { Coeff. Not } \\
\text { Signif. } 5 \% \\
\text { Level }\end{array}$ & $\begin{array}{c}\text { \% Firms } \\
\text { with <0 } \\
\text { Coefficient } \\
\text { Signif. 5\% } \\
\text { Level }\end{array}$ & $\begin{array}{c}\text { Median } \\
\text { SUM }_{E} \\
\text { coefficient }\end{array}$ & $\begin{array}{c}\text { p-value } \\
\text { (Median } \\
\text { SUM }_{E} \\
\text { coefficient) }\end{array}$ \\
\hline \multicolumn{9}{|c|}{ Panel A: Spread } \\
\hline World (All Exchanges) & 0.5986 & 0.4271 & $48.78 \%$ & $37.52 \%$ & $13.06 \%$ & $0.64 \%$ & 0.4327 & 0.000 \\
\hline \multicolumn{9}{|l|}{ Developed Markets: } \\
\hline Europe & 0.4992 & 0.2526 & $24.81 \%$ & $53.03 \%$ & $21.18 \%$ & $0.98 \%$ & 0.2776 & 0.000 \\
\hline North America & 0.6529 & 0.4563 & $47.88 \%$ & $39.42 \%$ & $12.28 \%$ & $0.42 \%$ & 0.4447 & 0.000 \\
\hline Pacific & 0.6123 & 0.3426 & $49.58 \%$ & $37.42 \%$ & $12.10 \%$ & $0.90 \%$ & 0.3558 & 0.000 \\
\hline All Developed Markets & 0.6036 & 0.3733 & $42.59 \%$ & $42.27 \%$ & $14.45 \%$ & $0.69 \%$ & 0.3783 & 0.000 \\
\hline \multicolumn{9}{|l|}{ Emerging Markets: } \\
\hline Asia & 0.6586 & 0.6357 & $73.61 \%$ & $20.44 \%$ & $5.67 \%$ & $0.29 \%$ & 0.6134 & 0.000 \\
\hline Europe, Middle East, Africa & 0.2276 & 0.3010 & $34.50 \%$ & $45.03 \%$ & $19.30 \%$ & $1.17 \%$ & 0.4628 & 0.000 \\
\hline Latin America & -0.0255 & 0.0100 & $5.81 \%$ & $47.74 \%$ & $43.87 \%$ & $2.58 \%$ & 0.0083 & 0.874 \\
\hline All Emerging Markets & 0.5845 & 0.5677 & $66.52 \%$ & $23.92 \%$ & $9.07 \%$ & $0.49 \%$ & 0.5703 & 0.000 \\
\hline \multicolumn{9}{|c|}{ Panel B: Depth } \\
\hline World (All Exchanges) & 0.6205 & 0.5204 & $41.54 \%$ & $42.60 \%$ & $15.46 \%$ & $0.40 \%$ & 0.5343 & 0.000 \\
\hline \multicolumn{9}{|l|}{ Developed Markets: } \\
\hline Europe & 0.3610 & 0.0815 & $22.78 \%$ & $45.38 \%$ & $31.31 \%$ & $0.53 \%$ & 0.0444 & 0.000 \\
\hline North America & 0.7946 & 0.7638 & $38.86 \%$ & $46.38 \%$ & $14.41 \%$ & $0.36 \%$ & 0.8082 & 0.000 \\
\hline Pacific & 0.4232 & 0.3979 & $37.40 \%$ & $47.17 \%$ & $14.89 \%$ & $0.54 \%$ & 0.3827 & 0.000 \\
\hline All Developed Markets & 0.6082 & 0.4924 & $35.54 \%$ & $46.43 \%$ & $17.59 \%$ & $0.44 \%$ & 0.4828 & 0.000 \\
\hline \multicolumn{9}{|l|}{ Emerging Markets: } \\
\hline Asia & 0.6876 & 0.6141 & $60.65 \%$ & $32.47 \%$ & $6.69 \%$ & $0.19 \%$ & 0.6828 & 0.000 \\
\hline Europe, Middle East, Africa & 0.7559 & 0.6952 & $56.36 \%$ & $28.48 \%$ & $13.94 \%$ & $1.21 \%$ & 0.7638 & 0.000 \\
\hline Latin America & 0.1191 & 0.0011 & $14.01 \%$ & $38.22 \%$ & $47.13 \%$ & $0.64 \%$ & 0.0025 & 0.428 \\
\hline All Emerging Markets & 0.6553 & 0.5792 & $57.33 \%$ & $32.57 \%$ & $9.81 \%$ & $0.29 \%$ & 0.6496 & 0.000 \\
\hline
\end{tabular}

Note: Firm-by-firm $(9,427)$ time-series regressions of liquidity measures are estimated using:

$\Delta$ Liquidity $_{F, t}=\alpha+\beta_{1} \Delta_{\text {Liquidity }}+,+\beta_{2} \Delta$ Liquidity $_{E, t+1}+\beta_{3} \Delta$ Liquidity $_{E, t-1}+\delta_{1}$ Return $_{E, t}+\delta_{2}$ Return $_{E, t+1}+\delta_{3}$ Return $_{E, t-1}+\delta_{4} \Delta V_{\text {Volatility }}+t+\varepsilon_{F, t}$ 
Liquidity $_{F, t}$ is the relative effective spread (Panel A) and the total depth in value (Panel B) of firm $F$ on day $t$. Liquidity E $_{t,}$ is the exchange-level liquidity index and Return $_{E, t}$ is the exchange-level return computed on day $t$ using an equal-weighted average of each corresponding liquidity measure and return, respectively, for all firms trading on the same exchange, except firm $F$. Volatility $y_{F, t}$ is the return volatility for firm $F$ on day $t$ and is measured as the squared return for the day. The symbol $\Delta$ preceding a variable name denotes a proportional change in the variable across successive trading days. We present the average and median coefficient estimate of the exchange-level liquidity beta $\beta_{1}$, along with the percent of firms for which $\beta_{1}$ is positive and significant at the $5 \%$ confidence level (t-statistic $>$ 1.645), positive and not significant at the 5\% confidence level, negative and not significant at the $5 \%$ confidence level, and negative and significant at the $5 \%$ confidence level, respectively. We report in the last two columns the median of the sum of the concurrent, lead and lag coefficient estimates $\left(\mathrm{SUM}_{E}=\beta_{1}+\beta_{2}+\right.$ $\left.\beta_{3}\right)$ and the p-value of a sign test testing whether Median $\left(\mathrm{SUM}_{E}\right)=0$. 
Table 5: Exchange-Level Commonality: Results by Size Quintile

\begin{tabular}{|c|c|c|c|c|c|c|c|c|}
\hline & $\begin{array}{l}\text { Average } \\
\text { Coef. }\end{array}$ & $\begin{array}{l}\text { Median } \\
\text { Coef. }\end{array}$ & $\begin{array}{c}\% \text { Firms } \\
\text { with }>0 \\
\text { Coefficient } \\
\text { Signif. 5\% } \\
\text { Level }\end{array}$ & $\begin{array}{c}\% \text { Firms } \\
\text { with }>0 \\
\text { Coeff. Not } \\
\text { Signif. } 5 \% \\
\text { Level }\end{array}$ & $\begin{array}{c}\% \text { Firms } \\
\text { with }<0 \\
\text { Coeff. Not } \\
\text { Signif. } 5 \% \\
\text { Level }\end{array}$ & $\begin{array}{c}\% \text { Firms } \\
\text { with }<0 \\
\text { Coefficient } \\
\text { Signif. 5\% } \\
\text { Level }\end{array}$ & $\begin{array}{c}\text { Median } \\
\text { SUM }_{E} \\
\text { coefficient }\end{array}$ & $\begin{array}{c}\text { p-value } \\
\text { (Median } \\
\text { SUM }_{E} \\
\text { coefficient) }\end{array}$ \\
\hline \multicolumn{9}{|c|}{ Panel A: Spread } \\
\hline Quintile 1 (Smallest Firms) & 0.6909 & 0.5215 & $45.14 \%$ & $38.89 \%$ & $15.06 \%$ & $0.91 \%$ & 0.5648 & 0.000 \\
\hline Quintile 2 & 0.7231 & 0.6164 & $56.91 \%$ & $32.75 \%$ & $9.87 \%$ & $0.48 \%$ & 0.5990 & 0.000 \\
\hline Quintile 3 & 0.6744 & 0.5267 & $57.04 \%$ & $31.98 \%$ & $10.61 \%$ & $0.37 \%$ & 0.5357 & 0.000 \\
\hline Quintile 4 & 0.5062 & 0.3702 & $48.35 \%$ & $37.57 \%$ & $13.45 \%$ & $0.64 \%$ & 0.3558 & 0.000 \\
\hline Quintile 5 (Largest Firms) & 0.3986 & 0.2142 & $36.46 \%$ & $46.43 \%$ & $16.31 \%$ & $0.80 \%$ & 0.2176 & 0.000 \\
\hline \multicolumn{9}{|c|}{ Panel B: Depth } \\
\hline Quintile 1 (Smallest Firms) & 0.5016 & 0.3339 & $27.26 \%$ & $46.97 \%$ & $24.69 \%$ & $1.09 \%$ & 0.3305 & 0.000 \\
\hline Quintile 2 & 0.5930 & 0.4742 & $34.93 \%$ & $47.26 \%$ & $17.35 \%$ & $0.45 \%$ & 0.5324 & 0.000 \\
\hline Quintile 3 & 0.6318 & 0.5446 & $39.44 \%$ & $44.05 \%$ & $16.39 \%$ & $0.11 \%$ & 0.5519 & 0.000 \\
\hline Quintile 4 & 0.6362 & 0.5711 & $44.22 \%$ & $43.82 \%$ & $11.72 \%$ & $0.23 \%$ & 0.5728 & 0.000 \\
\hline Quintile 5 (Largest Firms) & 0.7416 & 0.6876 & $62.14 \%$ & $30.69 \%$ & $7.05 \%$ & $0.12 \%$ & 0.6574 & 0.000 \\
\hline
\end{tabular}

Note: Firm-by-firm $(9,427)$ time-series regressions of liquidity measures are estimated using:

$\Delta$ Liquidity $_{F, t}=\alpha+\beta_{1}$ LLiquidity $_{E, t}+\beta_{2}$ LLiquidity $_{E, t+1}+\beta_{3}$ LLiquidity $_{E, t-1}+\delta_{1}$ Return $_{E, t}+\delta_{2}$ Return $_{E, t+1}+\delta_{3}$ Return $_{E, t-1}+\delta_{4} \Delta$ Volatility $_{F, t}+\varepsilon_{F, t}$

Liquidity $_{F, t}$ is the relative effective spread (Panel A) and the total depth in value (Panel B) of firm $F$ on day $t$. Liquidity L $_{E, t}$ is the exchange-level liquidity index and Return $_{E, t}$ is the exchange-level return computed on day $t$ using an equal-weighted average of each corresponding liquidity measure and return, respectively, for all firms trading on the same exchange, except firm $F$. Volatility ${ }_{F, t}$ is the return volatility for firm $F$ on day $t$ and is measured as the squared return for the day. The symbol $\Delta$ preceding a variable name denotes a proportional change in the variable across successive trading days. We present the average and median coefficient estimate of the exchange-level liquidity beta $\beta_{1}$, along with the percent of firms for which $\beta_{1}$ is positive and significant at the $5 \%$ confidence level (t-statistic $>$ 1.645 ), positive and not significant at the 5\% confidence level, negative and not significant at the $5 \%$ confidence level, and negative and significant at the $5 \%$ confidence level, respectively. We report in the last two columns the median of the sum of the concurrent, lead and lag coefficient estimates $\left(\mathrm{SUM} \mathrm{M}_{E}=\beta_{1}+\beta_{2}+\right.$ $\left.\beta_{3}\right)$ and the $\mathrm{p}$-value of a sign test testing whether Median $\left(\mathrm{SUM}_{E}\right)=0$. Results are presented by size-quintile. 
Table 6: Exchange-Level Commonality: Results by Industry

\begin{tabular}{|c|c|c|c|c|c|c|c|c|}
\hline $\begin{array}{c}\text { Industry } \\
\text { (Number of Firms) }\end{array}$ & $\begin{array}{l}\text { Average } \\
\text { Coef. }\end{array}$ & $\begin{array}{l}\text { Median } \\
\text { Coef. }\end{array}$ & $\begin{array}{c}\% \text { Firms } \\
\text { with >0 } \\
\text { Coefficient } \\
\text { Signif. 5\% } \\
\text { Level }\end{array}$ & $\begin{array}{c}\% \text { Firms } \\
\text { with }>0 \\
\text { Coeff. Not } \\
\text { Signif. } 5 \% \\
\text { Level }\end{array}$ & $\begin{array}{c}\% \text { Firms } \\
\text { with }<0 \\
\text { Coeff. Not } \\
\text { Signif. } 5 \% \\
\text { Level }\end{array}$ & $\begin{array}{c}\% \text { Firms } \\
\text { with <0 } \\
\text { Coefficient } \\
\text { Signif. 5\% } \\
\text { Level }\end{array}$ & $\begin{array}{c}\text { Median } \\
\text { SUM }_{E} \\
\text { coefficient }\end{array}$ & $\begin{array}{c}\text { p-value } \\
\text { (Median } \\
\text { SUM }_{E} \\
\text { coefficient) }\end{array}$ \\
\hline \multicolumn{9}{|c|}{ Panel A: Spread } \\
\hline Basic Material (769) & 0.6387 & 0.4677 & $40.55 \%$ & $43.44 \%$ & $15.49 \%$ & $0.52 \%$ & 0.5158 & 0.000 \\
\hline Communications (732) & 0.6998 & 0.5522 & $47.18 \%$ & $36.86 \%$ & $14.86 \%$ & $1.10 \%$ & 0.5880 & 0.000 \\
\hline Consumer Cyclical $(1,642)$ & 0.7532 & 0.6164 & $55.24 \%$ & $33.31 \%$ & $10.59 \%$ & $0.86 \%$ & 0.6103 & 0.000 \\
\hline Consumer Non-Cyclic. $(1,590)$ & 0.6993 & 0.5840 & $58.65 \%$ & $30.56 \%$ & $10.48 \%$ & $0.32 \%$ & 0.5694 & 0.000 \\
\hline Diversified (137) & 0.5909 & 0.5090 & $56.93 \%$ & $32.85 \%$ & $10.22 \%$ & $0.00 \%$ & 0.4809 & 0.000 \\
\hline Energy (310) & 0.6643 & 0.4991 & $55.34 \%$ & $35.92 \%$ & $8.74 \%$ & $0.00 \%$ & 0.5189 & 0.000 \\
\hline Financial $(1,570)$ & 0.5513 & 0.4159 & $51.31 \%$ & $35.28 \%$ & $13.02 \%$ & $0.38 \%$ & 0.4040 & 0.000 \\
\hline Industrial $(1,731)$ & 0.4469 & 0.2867 & $41.45 \%$ & $41.86 \%$ & $15.76 \%$ & $0.93 \%$ & 0.2777 & 0.000 \\
\hline Technology (662) & 0.4252 & 0.2081 & $35.66 \%$ & $48.71 \%$ & $15.02 \%$ & $0.61 \%$ & 0.2174 & 0.000 \\
\hline Utilities (284) & 0.2932 & 0.1216 & $32.51 \%$ & $50.53 \%$ & $15.90 \%$ & $1.06 \%$ & 0.1345 & 0.000 \\
\hline \multicolumn{9}{|c|}{ Panel B: Depth } \\
\hline Basic Material (769) & 0.4937 & 0.3061 & $23.44 \%$ & $48.54 \%$ & $26.91 \%$ & $1.11 \%$ & 0.2820 & 0.000 \\
\hline Communications (732) & 0.4991 & 0.3504 & $28.34 \%$ & $47.48 \%$ & $23.15 \%$ & $1.04 \%$ & 0.3502 & 0.000 \\
\hline Consumer Cyclical $(1,642)$ & 0.5740 & 0.4467 & $34.05 \%$ & $46.72 \%$ & $18.71 \%$ & $0.52 \%$ & 0.4982 & 0.000 \\
\hline Consumer Non-Cyclic. $(1,590)$ & 0.6311 & 0.5251 & $38.09 \%$ & $44.26 \%$ & $17.31 \%$ & $0.34 \%$ & 0.5441 & 0.000 \\
\hline Diversified (137) & 0.6795 & 0.6122 & $41.41 \%$ & $44.53 \%$ & $14.06 \%$ & $0.00 \%$ & 0.5578 & 0.000 \\
\hline Energy (310) & 0.6223 & 0.5188 & $38.64 \%$ & $42.71 \%$ & $18.31 \%$ & $0.34 \%$ & 0.4588 & 0.000 \\
\hline Financial $(1,570)$ & 0.6011 & 0.5636 & $40.86 \%$ & $45.86 \%$ & $13.00 \%$ & $0.27 \%$ & 0.5625 & 0.000 \\
\hline Industrial $(1,731)$ & 0.7000 & 0.6150 & $51.52 \%$ & $38.58 \%$ & $9.83 \%$ & $0.06 \%$ & 0.6172 & 0.000 \\
\hline Technology (662) & 0.7479 & 0.6987 & $67.77 \%$ & $27.93 \%$ & $4.13 \%$ & $0.17 \%$ & 0.6696 & 0.000 \\
\hline Utilities (284) & 0.7928 & 0.7817 & $74.23 \%$ & $19.23 \%$ & $6.54 \%$ & $0.00 \%$ & 0.7101 & 0.000 \\
\hline
\end{tabular}

Note: Firm-by-firm $(9,427)$ time-series regressions of liquidity measures are estimated using:

$$
\Delta \text { Liquidity }_{F, t}=\alpha+\beta_{1} \Delta_{\text {Liquidity }} \text { L }, t+\beta_{2} \Delta \text { Liquidity }_{E, t+1}+\beta_{3} \Delta \text { Liquidity }_{E, t-1}+\delta_{1} \text { Return }_{E, t}+\delta_{2} \text { Return }_{E, t+1}+\delta_{3} \text { Return }_{E, t-1}+\delta_{4} \Delta \text { Volatility }_{F, t}+\varepsilon_{F, t}
$$

Liquidity $_{F, t}$ is the relative effective spread (Panel A) and the total depth in value (Panel B) of firm $F$ on day $t$. Liquidity ${ }_{E, t}$ is the exchange-level liquidity index and Return $_{E, t}$ is the exchange-level return computed on day $t$ using an equal-weighted average of each corresponding liquidity measure and return, respectively, for all firms trading on the same exchange, except firm $F$. Volatility ${ }_{F, t}$ is the return volatility for firm $F$ on day $t$ and is measured as the squared return for the day. The symbol $\Delta$ preceding a variable name denotes a proportional change in the variable across successive trading days. We present the average and median coefficient estimate of the exchange-level liquidity beta $\beta_{1}$, along with the percent of firms for which $\beta_{1}$ is positive and significant at the $5 \%$ confidence level (t-statistic $>$ 
1.645), positive and not significant at the $5 \%$ confidence level, negative and not significant at the $5 \%$ confidence level, and negative and significant at the $5 \%$ confidence level, respectively. We report in the last two columns the median of the sum of the concurrent, lead and lag coefficient estimates $\left(\mathrm{SUM} \mathrm{M}_{E}=\beta_{1}+\beta_{2}+\right.$ $\left.\beta_{3}\right)$ and the $\mathrm{p}$-value of a sign test testing whether Median $\left(\mathrm{SUM}_{E}\right)=0$. Results are presented by industry.

Table 7: Exchange-Level and Industry Commonality

\begin{tabular}{|c|c|c|c|c|c|c|c|c|c|}
\hline & & $\begin{array}{c}\text { Average } \\
\text { Coef. }\end{array}$ & $\begin{array}{c}\text { Median } \\
\text { Coef. }\end{array}$ & $\begin{array}{c}\% \text { Firms } \\
\text { with }>0 \\
\text { Coefficient } \\
\text { Signif. 5\% } \\
\text { Level }\end{array}$ & $\begin{array}{c}\% \text { Firms } \\
\text { with }>0 \\
\text { Coeff. Not } \\
\text { Signif. 5\% } \\
\text { Level }\end{array}$ & $\begin{array}{c}\% \text { Firms } \\
\text { with }<0 \\
\text { Coeff. Not } \\
\text { Signif. 5\% } \\
\text { Level }\end{array}$ & $\begin{array}{c}\% \text { Firms } \\
\text { with <0 } \\
\text { Coefficient } \\
\text { Signif. 5\% } \\
\text { Level }\end{array}$ & $\begin{array}{c}\text { Median } \\
\text { SUM }_{i} \\
\text { coefficient }\end{array}$ & $\begin{array}{c}\text { p-value } \\
\text { (Median } \\
\text { SUM }_{i} \\
\text { coefficient) }\end{array}$ \\
\hline \multicolumn{10}{|c|}{ Panel A: Spread } \\
\hline \multirow[t]{2}{*}{ World (All Exchanges) } & $\beta_{1}$ & 0.4966 & 0.3377 & $29.91 \%$ & $49.61 \%$ & $19.32 \%$ & $1.16 \%$ & 0.3157 & 0.000 \\
\hline & $\gamma_{1}$ & 0.1064 & 0.0334 & $10.50 \%$ & $47.65 \%$ & $38.58 \%$ & $3.27 \%$ & 0.0344 & 0.000 \\
\hline \multirow[t]{2}{*}{ All Developed Markets } & $\beta_{1}$ & 0.4796 & 0.2864 & $24.58 \%$ & $52.88 \%$ & $21.23 \%$ & $1.32 \%$ & 0.2710 & 0.000 \\
\hline & $\gamma_{1}$ & 0.1254 & 0.0340 & $10.07 \%$ & $48.09 \%$ & $38.79 \%$ & $3.05 \%$ & 0.0331 & 0.000 \\
\hline \multirow[t]{2}{*}{ All Emerging Markets } & $\beta_{1}$ & 0.5456 & 0.4855 & $45.26 \%$ & $40.22 \%$ & $13.81 \%$ & $0.71 \%$ & 0.4527 & 0.000 \\
\hline & $\gamma_{1}$ & 0.0518 & 0.0304 & $11.73 \%$ & $46.38 \%$ & $37.98 \%$ & $3.91 \%$ & 0.0375 & 0.000 \\
\hline \multicolumn{10}{|c|}{ Panel B: Depth } \\
\hline \multirow[t]{2}{*}{ World (All Exchanges) } & $\beta_{1}$ & 0.4983 & 0.4052 & $27.02 \%$ & $50.01 \%$ & $21.89 \%$ & $1.09 \%$ & 0.3932 & 0.000 \\
\hline & $\gamma_{1}$ & 0.1315 & 0.0749 & $13.25 \%$ & $47.66 \%$ & $36.10 \%$ & $3.00 \%$ & 0.0799 & 0.000 \\
\hline \multirow[t]{2}{*}{ All Developed Markets } & $\beta_{1}$ & 0.4690 & 0.3644 & $21.99 \%$ & $52.28 \%$ & $24.47 \%$ & $1.25 \%$ & 0.3122 & 0.000 \\
\hline & $\gamma_{1}$ & 0.1468 & 0.0787 & $12.80 \%$ & $47.91 \%$ & $36.53 \%$ & $2.77 \%$ & 0.0854 & 0.009 \\
\hline \multirow[t]{2}{*}{ All Emerging Markets } & $\beta_{1}$ & 0.5753 & 0.4934 & $40.23 \%$ & $44.01 \%$ & $15.09 \%$ & $0.67 \%$ & 0.5439 & 0.000 \\
\hline & $\gamma_{1}$ & 0.0912 & 0.0662 & $14.42 \%$ & $47.01 \%$ & $34.95 \%$ & $3.62 \%$ & 0.0711 & 0.000 \\
\hline
\end{tabular}

Note: Firm-by-firm $(9,427)$ time-series regressions of liquidity measures are estimated using:

$$
\begin{gathered}
\text { LLiquidity }_{F, t}=\alpha+\beta_{1} \text { ALiquidity }_{E, t}+\beta_{2} \text { LLiquidity }_{E, t+1}+\beta_{3} \text { LLiquidity }_{E, t-1}+\gamma_{1} \text { ALiquidity }_{E I, t}+\gamma_{2} \text { ALiquidity }_{E I, t+1}+\gamma_{3} \Delta \text { Liquidity }_{E I, t-1} \\
+\delta_{1} \text { Return }_{E, t}+\delta_{2} \text { Return }_{E, t+1}+\delta_{3} \text { Return }_{E, t-1}+\delta_{4} \Delta \text { Volatility }_{F, t}+\varepsilon_{F, t}
\end{gathered}
$$

Liquidity $_{F, t}$ is the relative effective spread (Panel A) and the total depth in value (Panel B) of firm $F$ on day $t$. Liquidity Lit $_{\text {is }}$ the exchange-level liquidity index and Return $_{E, t}$ is the exchange-level return computed on day $t$ using an equal-weighted average of each corresponding liquidity measure and return, respectively, for all firms trading on the same exchange, except firm $F$. Liquidity ${ }_{E I, t}$ is the industry-level liquidity index computed on day $t$ using an equal-weighted average of each corresponding liquidity measure for all firms in firm $F$ 's industry. Volatility $y_{, t}$ is the return volatility for firm $F$ on day $t$ and is measured as the squared return for the day. The symbol $\Delta$ preceding a variable name denotes a proportional change in the variable across successive trading days. We present the average and median coefficient estimate of the exchange-level and industry-level liquidity betas $\beta_{1}$, and $\gamma_{1}$, along with the percent of firms for which $\beta_{1}$, or $\gamma_{1}$, is positive and significant at the $5 \%$ confidence level (t-statistic $>1.645$ ), positive and not significant at the $5 \%$ confidence level, negative and not significant at the $5 \%$ confidence level, and negative and significant at the 5\% confidence level, respectively. We report in the last two columns the median of the sum of the 
concurrent, lead and lag coefficient estimates $\left(\mathrm{SUM}_{E}=\beta_{1}+\beta_{2}+\beta_{3}\right.$ and $\left.\mathrm{SUM}_{E I}=\gamma_{1}+\gamma_{2}+\gamma_{3}\right)$ and the p-value of a sign test testing whether Median $\left(\mathrm{SUM}_{E}\right)=0$ and Median $\left(\mathrm{SUM}_{E I}\right)=0$.

Table 8: Global Commonality

\begin{tabular}{|c|c|c|c|c|c|c|c|c|}
\hline & $\begin{array}{c}\text { Average } \\
\text { Coef. }\end{array}$ & $\begin{array}{l}\text { Median } \\
\text { Coef. }\end{array}$ & $\begin{array}{c}\% \text { Firms } \\
\text { with }>0 \\
\text { Coefficient } \\
\text { Signif. 5\% } \\
\text { Level }\end{array}$ & $\begin{array}{c}\% \text { Firms } \\
\text { with }>0 \\
\text { Coeff. Not } \\
\text { Signif. 5\% } \\
\text { Level }\end{array}$ & $\begin{array}{c}\% \text { Firms } \\
\text { with }<0 \\
\text { Coeff. Not } \\
\text { Signif. 5\% } \\
\text { Level }\end{array}$ & $\begin{array}{c}\% \text { Firms } \\
\text { with }<0 \\
\text { Coefficient } \\
\text { Signif. 5\% } \\
\text { Level }\end{array}$ & $\begin{array}{c}\text { Median } \\
\text { SUM }_{G} \\
\text { coefficient }\end{array}$ & $\begin{array}{c}\text { p-value } \\
\text { (Median } \\
\text { SUM }_{G} \\
\text { coefficient) }\end{array}$ \\
\hline \multicolumn{9}{|c|}{ Panel A: Spread } \\
\hline World (All Exchanges) & 0.1753 & 0.1764 & $44.68 \%$ & $38.30 \%$ & $14.89 \%$ & $2.13 \%$ & 0.2275 & 0.000 \\
\hline Developed Markets & 0.2494 & 0.2440 & $59.26 \%$ & $25.93 \%$ & $14.81 \%$ & $0.00 \%$ & 0.2546 & 0.006 \\
\hline Emerging Markets & 0.0752 & 0.1296 & $25.00 \%$ & $55.00 \%$ & $15.00 \%$ & $5.00 \%$ & 0.1234 & 0.041 \\
\hline \multicolumn{9}{|c|}{ Panel B: Depth } \\
\hline World (All Exchanges) & 0.0674 & 0.0352 & $26.67 \%$ & $46.67 \%$ & $22.22 \%$ & $4.44 \%$ & 0.0750 & 0.008 \\
\hline Developed Markets & 0.0711 & 0.0404 & $32.00 \%$ & $40.00 \%$ & $24.00 \%$ & $4.00 \%$ & 0.1055 & 0.052 \\
\hline Emerging Markets & 0.0628 & 0.0325 & $20.00 \%$ & $55.00 \%$ & $20.00 \%$ & $5.00 \%$ & 0.0614 & 0.115 \\
\hline
\end{tabular}

Note: Exchange-by-exchange (47) time-series regressions of liquidity measures are estimated using:

$$
\Delta \text { Liquidity }_{E, t}=\alpha+\beta_{1} \Delta \text { Liquidity }_{G, t}+\beta_{2} \Delta \text { Liquidity }_{G, t+1}+\beta_{3} \Delta \text { Liquidity }_{G,-1}+\delta_{1} \text { Return }_{G, t}+\delta_{2} \text { Return }_{G, t+1}+\delta_{3} \text { Return }_{G, t-1}+\delta_{4} \Delta \text { Volatility }_{E, t}+\varepsilon_{E, t}
$$

Liquidity $_{E, t}$ is the exchange-level average relative effective spread (Panel A) and total depth in value (Panel B) of exchange $E$ on day $t$. Liquidity ${ }_{G, t}$ is the global liquidity index and Return $n_{G, t}$ is the global return computed on day $t$ using an equal-weighted average of each corresponding liquidity measure and return, respectively, for all firms, except those firms trading on exchange $E$. Volatility $y_{E, t}$ is the return volatility for firms trading on exchange $E$ on day $t$ and is measured as the squared return for the day. The symbol $\Delta$ preceding a variable name denotes a proportional change in the variable across successive trading days. We present the average and median coefficient estimate of the exchange-level liquidity beta $\beta_{1}$, along with the percent of firms for which $\beta_{1}$ is positive and significant at the $5 \%$ confidence level (t-statistic $>1.645$ ), positive and not significant at the $5 \%$ confidence level, negative and not significant at the $5 \%$ confidence level, and negative and significant at the 5\% confidence level, respectively. We report in the last two columns the median of the sum of the concurrent, lead and lag coefficient estimates $\left(\mathrm{SUM}_{G}=\beta_{1}+\beta_{2}+\beta_{3}\right)$ and the p-value of a sign test testing whether Median $\left(\mathrm{SUM}_{G}\right)=0$. 
Table 9: Global Commonality and Exchange Size

\begin{tabular}{|c|c|c|c|c|c|c|c|c|}
\hline & $\begin{array}{c}\text { Average } \\
\text { Coef. }\end{array}$ & $\begin{array}{l}\text { Median } \\
\text { Coef. }\end{array}$ & $\begin{array}{c}\% \text { Firms } \\
\text { with }>0 \\
\text { Coefficient } \\
\text { Signif. 5\% } \\
\text { Level }\end{array}$ & $\begin{array}{c}\% \text { Firms } \\
\text { with }>0 \\
\text { Coeff. Not } \\
\text { Signif. 5\% } \\
\text { Level }\end{array}$ & $\begin{array}{c}\% \text { Firms } \\
\text { with }<0 \\
\text { Coeff. Not } \\
\text { Signif. 5\% } \\
\text { Level }\end{array}$ & $\begin{array}{c}\% \text { Firms } \\
\text { with }<0 \\
\text { Coefficient } \\
\text { Signif. 5\% } \\
\text { Level }\end{array}$ & $\begin{array}{c}\text { Median } \\
\text { SUM }_{G} \\
\text { coefficient }\end{array}$ & $\begin{array}{c}\text { p-value } \\
\text { (Median } \\
\text { SUM }_{G} \\
\text { coefficient) }\end{array}$ \\
\hline \multicolumn{9}{|c|}{ Panel A: Spread } \\
\hline Small Markets & 0.1664 & 0.1296 & $31.25 \%$ & $50.00 \%$ & $18.75 \%$ & $0.00 \%$ & 0.2564 & 0.077 \\
\hline Medium Markets & 0.1572 & 0.1765 & $33.33 \%$ & $46.67 \%$ & $13.33 \%$ & $6.67 \%$ & 0.1282 & 0.119 \\
\hline Large Markets & 0.2011 & 0.2075 & $68.75 \%$ & $18.75 \%$ & $12.50 \%$ & $0.00 \%$ & 0.2410 & 0.021 \\
\hline \multicolumn{9}{|c|}{ Panel B: Depth } \\
\hline Small Markets & 0.0926 & 0.0812 & $31.25 \%$ & $50.00 \%$ & $18.75 \%$ & $0.00 \%$ & 0.1344 & 0.077 \\
\hline Medium Markets & 0.0758 & 0.0315 & $28.57 \%$ & $28.57 \%$ & $35.71 \%$ & $7.14 \%$ & 0.0481 & 0.607 \\
\hline Large Markets & 0.0329 & 0.0348 & $20.00 \%$ & $60.00 \%$ & $13.33 \%$ & $6.67 \%$ & 0.0635 & 0.077 \\
\hline
\end{tabular}

Note: Exchange-by-exchange (47) time-series regressions of liquidity measures are estimated using:

$$
\Delta \text { Liquidity }_{E, t}=\alpha+\beta_{1} \text { ALiquidity }_{G, t}+\beta_{2} \text { LLiquidity }_{G, t+1}+\beta_{3} \Delta \text { Liquidity }_{G, t-1}+\delta_{1} \text { Return }_{G, t}+\delta_{2} \text { Return }_{G, t+1}+\delta_{3} \text { Return }_{G, t-1}+\delta_{4} \Delta \text { Volatility }_{E, t}+\varepsilon_{E, t}
$$

Liquidity $_{E, t}$ is the exchange-level average relative effective spread (Panel A) and total depth in value (Panel B) of exchange $E$ on day $t$. Liquidity,$t$ is the global liquidity index and Return $_{G, t}$ is the global return computed on day $t$ using an equal-weighted average of each corresponding liquidity measure and return, respectively, for all firms, except those firms trading on exchange $E$. Volatility ${ }_{E, t}$ is the return volatility for firms trading on exchange $E$ on day $t$ and is measured as the squared return for the day. The symbol $\Delta$ preceding a variable name denotes a proportional change in the variable across successive trading days. We present the average and median coefficient estimate of the exchange-level liquidity beta $\beta_{1}$, along with the percent of firms for which $\beta_{1}$ is positive and significant at the 5\% confidence level (t-statistic $>1.645$ ), positive and not significant at the $5 \%$ confidence level, negative and not significant at the $5 \%$ confidence level, and negative and significant at the $5 \%$ confidence level, respectively. We report in the last two columns the median of the sum of the concurrent, lead and lag coefficient estimates $\left(\mathrm{SUM}_{G}=\beta_{1}+\beta_{2}+\beta_{3}\right)$ and the $\mathrm{p}$-value of a sign test testing whether Median $\left(\mathrm{SUM} \mathrm{M}_{G}\right)=0$. Results are presented for the 16 smallest exchanges, 15 medium-size exchanges, and 16 largest exchanges. 
Table 10: Global and Regional Commonality

\begin{tabular}{|c|c|c|c|c|c|c|c|c|c|}
\hline & & $\begin{array}{c}\text { Average } \\
\text { Coef. }\end{array}$ & $\begin{array}{l}\text { Median } \\
\text { Coef. }\end{array}$ & $\begin{array}{c}\% \text { Firms } \\
\text { with }>0 \\
\text { Coefficient } \\
\text { Signif. 5\% } \\
\text { Level }\end{array}$ & $\begin{array}{c}\% \text { Firms } \\
\text { with }>0 \\
\text { Coeff. Not } \\
\text { Signif. } 5 \% \\
\text { Level }\end{array}$ & $\begin{array}{c}\text { \% Firms } \\
\text { with }<0 \\
\text { Coeff. Not } \\
\text { Signif. 5\% } \\
\text { Level }\end{array}$ & $\begin{array}{c}\% \text { Firms } \\
\text { with }<0 \\
\text { Coefficient } \\
\text { Signif. 5\% } \\
\text { Level }\end{array}$ & $\begin{array}{c}\text { Median } \\
\text { SUM }_{i} \\
\text { coefficient }\end{array}$ & $\begin{array}{c}\text { p-value } \\
\text { (Median } \\
\text { SUM }_{i} \\
\text { coefficient) }\end{array}$ \\
\hline \multicolumn{10}{|c|}{ Panel A: Spread } \\
\hline \multirow[t]{2}{*}{ World (All Exchanges) } & $\beta_{1}$ & 0.1231 & 0.1135 & $25.53 \%$ & $59.57 \%$ & $10.64 \%$ & $4.26 \%$ & 0.1852 & 0.001 \\
\hline & $\gamma_{1}$ & 0.1142 & 0.0475 & $23.40 \%$ & $46.81 \%$ & $25.53 \%$ & $4.26 \%$ & 0.0540 & 0.243 \\
\hline \multirow[t]{2}{*}{ All Developed Markets } & $\beta_{1}$ & 0.1553 & 0.1553 & $33.33 \%$ & $51.85 \%$ & $11.11 \%$ & $3.70 \%$ & 0.2327 & 0.052 \\
\hline & $\gamma_{1}$ & 0.1934 & 0.1873 & $33.33 \%$ & $48.15 \%$ & $18.52 \%$ & $0.00 \%$ & 0.1837 & 0.006 \\
\hline \multirow[t]{2}{*}{ All Emerging Markets } & $\beta_{1}$ & 0.0797 & 0.1012 & $15.00 \%$ & $70.00 \%$ & $10.00 \%$ & $5.00 \%$ & 0.1844 & 0.012 \\
\hline & $\gamma_{1}$ & 0.0073 & 0.0003 & $10.00 \%$ & $45.00 \%$ & $35.00 \%$ & $10.00 \%$ & -0.0131 & 0.263 \\
\hline \multicolumn{10}{|c|}{ Panel B: Depth } \\
\hline \multirow[t]{2}{*}{ World (All Exchanges) } & $\beta_{1}$ & 0.0479 & 0.0344 & $13.33 \%$ & $53.33 \%$ & $31.11 \%$ & $2.22 \%$ & 0.0725 & 0.040 \\
\hline & $\gamma_{1}$ & 0.0751 & 0.0398 & $26.67 \%$ & $46.67 \%$ & $24.44 \%$ & $2.22 \%$ & 0.0083 & 0.560 \\
\hline \multirow[t]{2}{*}{ All Developed Markets } & $\beta_{1}$ & 0.0398 & 0.0248 & $12.00 \%$ & $52.00 \%$ & $36.00 \%$ & $0.00 \%$ & 0.0908 & 0.122 \\
\hline & $\gamma_{1}$ & 0.1234 & 0.0546 & $32.00 \%$ & $48.00 \%$ & $20.00 \%$ & $0.00 \%$ & 0.0397 & 0.052 \\
\hline \multirow[t]{2}{*}{ All Emerging Markets } & $\beta_{1}$ & 0.0580 & 0.0482 & $15.00 \%$ & $55.00 \%$ & $25.00 \%$ & $5.00 \%$ & 0.0675 & 0.263 \\
\hline & $\gamma_{1}$ & 0.0147 & 0.0035 & $20.00 \%$ & $45.00 \%$ & $30.00 \%$ & $5.00 \%$ & -0.0113 & 0.263 \\
\hline
\end{tabular}

Note: Exchange-by-exchange (47) time-series regressions of liquidity measures are estimated using:

$\Delta$ Liquidity $_{E, t}=\alpha+\beta_{1} \Delta_{\text {Liquidity }_{G, t}}+\beta_{2}$ LLiquidity $_{G, t+1}+\beta_{3}$ LLiquidity $_{G, t-1}+\gamma_{1} \Delta$ Liquidity $_{R, t}+\gamma_{2} \Delta$ Liquidity $_{R, t+1}+\gamma_{3} \Delta$ Liquidity $_{R, t-1}$

$+\delta_{1}$ Return $_{G, t}+\delta_{2}$ Return $_{G, t+1}+\delta_{3}$ Return $_{G, t-1}+\delta_{4} \Delta$ Volatility $_{E, t}+\varepsilon_{E, t}$

Liquidity $_{E, t}$ is the exchange-level average relative effective spread (Panel A) and total depth in value (Panel B) of exchange $E$ on day $t$. Liquidity L $_{t, t}$ is the global liquidity index and Return $_{G, t}$ is the global return computed on day $t$ using an equal-weighted average of each corresponding liquidity measure and return, respectively, for all firms, except those firms trading on exchange E. Liquidity ${ }_{R, t}$ is the regional liquidity index computed on day $t$ using an equal-weighted average of each corresponding liquidity measure for all firms trading on an exchange located in the same region as exchange $E$. Volatility ${ }_{E, t}$ is the return volatility for firms trading on exchange $E$ on day $t$ and is measured as the squared return for the day. The symbol $\Delta$ preceding a variable name denotes a proportional change in the variable across successive trading days. We present the average and median coefficient estimate of the exchange-level liquidity beta $\beta_{1}$, along with the percent of firms for which $\beta_{1}$ is positive and significant at the $5 \%$ confidence level (t-statistic $>1.645$ ), positive and not significant at the 5\% confidence level, negative and not significant at the 5\% confidence level, and negative and significant at the 5\% confidence level, respectively. We report in the last two columns the median of the sum of the concurrent, lead and lag coefficient estimates $\left(\mathrm{SUM}_{G}=\beta_{1}+\beta_{2}+\beta_{3}\right.$ and SUM $\left.\mathrm{SU}_{R}=\gamma_{1}+\gamma_{2}+\gamma_{3}\right)$ and the p-value of a sign test testing whether Median $\left(\mathrm{SUM}_{G}\right)=0$ and Median $\left(\mathrm{SUM}_{R}\right)=0$. 
Table 11: Global Commonality: Adjustment for Large Markets

\begin{tabular}{|c|c|c|c|c|c|c|c|c|}
\hline & $\begin{array}{c}\text { Average } \\
\text { Coef. }\end{array}$ & $\begin{array}{l}\text { Median } \\
\text { Coef. }\end{array}$ & $\begin{array}{c}\% \text { Firms } \\
\text { with >0 } \\
\text { Coefficient } \\
\text { Signif. 5\% } \\
\text { Level }\end{array}$ & $\begin{array}{c}\% \text { Firms } \\
\text { with }>0 \\
\text { Coeff. Not } \\
\text { Signif. 5\% } \\
\text { Level }\end{array}$ & $\begin{array}{c}\% \text { Firms } \\
\text { with }<0 \\
\text { Coeff. Not } \\
\text { Signif. 5\% } \\
\text { Level }\end{array}$ & $\begin{array}{c}\% \text { Firms } \\
\text { with }<0 \\
\text { Coefficient } \\
\text { Signif. 5\% } \\
\text { Level }\end{array}$ & $\begin{array}{c}\text { Median } \\
\text { SUM }_{G} \\
\text { coefficient }\end{array}$ & $\begin{array}{c}\text { p-value } \\
\text { (Median } \\
\text { SUM }_{G} \\
\text { coefficient) }\end{array}$ \\
\hline \multicolumn{9}{|c|}{ Panel A: Spread } \\
\hline World & 0.1753 & 0.1764 & $44.68 \%$ & $38.30 \%$ & $14.89 \%$ & $2.13 \%$ & 0.2275 & 0.000 \\
\hline World but NYSE & 0.1911 & 0.1936 & $42.55 \%$ & $42.55 \%$ & $14.89 \%$ & $0.00 \%$ & 0.2633 & 0.003 \\
\hline World but NASDAQ & 0.1621 & 0.1835 & $44.68 \%$ & $40.43 \%$ & $14.89 \%$ & $0.00 \%$ & 0.2130 & 0.000 \\
\hline World but London Stock Ex. & 0.1679 & 0.1829 & $44.68 \%$ & $42.55 \%$ & $8.51 \%$ & $4.26 \%$ & 0.2313 & 0.000 \\
\hline World but Tokyo Stock Ex. & 0.1269 & 0.1480 & $36.17 \%$ & $44.68 \%$ & $17.02 \%$ & $2.13 \%$ & 0.1571 & 0.008 \\
\hline World but Four Largest Ex. & 0.0969 & 0.0864 & $34.04 \%$ & $42.55 \%$ & $23.40 \%$ & $0.00 \%$ & 0.0907 & 0.040 \\
\hline \multicolumn{9}{|c|}{ Panel B: Depth } \\
\hline World & 0.0674 & 0.0352 & $26.67 \%$ & $46.67 \%$ & $22.22 \%$ & $4.44 \%$ & 0.0750 & 0.008 \\
\hline World but NYSE & 0.0800 & 0.0522 & $24.44 \%$ & $51.11 \%$ & $22.22 \%$ & $2.22 \%$ & 0.0877 & 0.003 \\
\hline World but NASDAQ & 0.1066 & 0.0813 & $28.89 \%$ & $53.33 \%$ & $17.78 \%$ & $0.00 \%$ & 0.1144 & 0.000 \\
\hline World but London Stock Ex. & 0.0670 & 0.0344 & $22.22 \%$ & $51.11 \%$ & $22.22 \%$ & $4.44 \%$ & 0.0717 & 0.008 \\
\hline World but Tokyo Stock Ex. & 0.0474 & 0.0249 & $17.78 \%$ & $42.22 \%$ & $35.56 \%$ & $4.44 \%$ & 0.0525 & 0.144 \\
\hline World but Four Largest Ex. & 0.0922 & 0.0832 & $44.44 \%$ & $42.22 \%$ & $13.33 \%$ & $0.00 \%$ & 0.0875 & 0.003 \\
\hline
\end{tabular}

Note: Exchange-by-exchange (47) time-series regressions of liquidity measures are estimated using:

$$
\Delta \text { Liquidity }_{E, t}=\alpha+\beta_{1} \Delta_{\text {Liquidity }_{G, t}}+\beta_{2} \text { LLiquidity }_{G, t+1}+\beta_{3} \text { LLiquidity }_{G, t-1}+\delta_{1} \text { Return }_{G, t}+\delta_{2} \text { Return }_{G, t+1}+\delta_{3} \text { Return }_{G, t-1}+\delta_{4} \Delta \text { Volatility }_{E, t}+\varepsilon_{E, t}
$$

Liquidity $_{E, t}$ is the exchange-level average relative effective spread (Panel A) and total depth in value (Panel B) of exchange $E$ on day $t$. Liquidity ${ }_{G, t}$ is the global liquidity index and Return $_{G, t}$ is the global return computed on day $t$ using an equal-weighted average of each corresponding liquidity measure and return, respectively, for all firms, except those firms trading on exchange $E$ and firms listed on NYSE, NASDAQ, London Stock Exchange, or Tokyo Stock Exchange. Volatility $_{E, t}$ is the return volatility for firms trading on exchange $E$ on day $t$ and is measured as the squared return for the day. The symbol $\Delta$ preceding a variable name denotes a proportional change in the variable across successive trading days. We present the average and median coefficient estimate of the exchange-level liquidity beta $\beta_{1}$, along with the percent of firms for which $\beta_{1}$ is positive and significant at the 5\% confidence level (t-statistic $>1.645$ ), positive and not significant at the 5\% confidence level, negative and not significant at the $5 \%$ confidence level, and negative and significant at the $5 \%$ confidence level, respectively. We report in the last two columns the median of the sum of the concurrent, lead and lag coefficient estimates $\left(\mathrm{SUM} \mathrm{M}_{G}=\beta_{1}+\beta_{2}+\beta_{3}\right)$ and the $\mathrm{p}-$ value of a sign test testing whether Median $\left(\mathrm{SUM}_{G}\right)=0$. 